\title{
Systematic studies in the eucalypts. 8. A review of the Eudesmioid eucalypts, Eucalyptus subgenus Eudesmia (Myrtaceae)
}

\author{
K.D. Hill and L.A.S. Johnson ${ }^{\dagger}$
}

\begin{abstract}
Hill, K.D. and Johnson, L.A.S. (National Herbarium of New South Wales, Royal Botanic Gardens, Sydney, Australia 2000) 1998. Systematic studies in the eucalypts. 8. A review of the Eudesmioid eucalypts, Eucalyptus subgenus Eudesmia (Myrtaceae). Telopea 7(4): 375-414. A revision of Eucalyptus subgenus Eudesmia is presented. A formal combination is made for subgenus Eudesmia. 22 species are included, three of them described as new (Eucalyptus pallida, E. selachiana, E. conveniens), with one new subspecies (E. ebbanoensis subsp. glauciramula). Long-standing misapplication of the name E. tetragona is corrected, the name E. pleurocarpa Schauer reinstated from synonymy, and a lectotype is designated for E. phoenicea. Relationships within the group are discussed, and an infrageneric classification is presented, with keys to subgroupings and species.
\end{abstract}

\section{Introduction}

The extracodical subgenus Eudesmia of Pryor \& Johnson (1971) is a diverse and rather heterogeneous assemblage. Although the group has been suggested to be paraphyletic (Ladiges \& Humphries 1983), our studies in the eucalypt group generally (Hill \& Johnson 1995) and later studies by others (Ladiges et al. 1995) indicate that the group is probably monophyletic. Analysis of character sets based on morphological data at this level show a high degree of homoplasy, and have proven to be inadequate in fully resolving relationships. While few of the defining characters are apomorphic and exclusive to the group in the context of the Eudesmia and Eucalyptus suballiances of Johnson \& Briggs (1984), several natural monophyletic units may be recognised within the group. It is here treated as a subgenus with the same circumscription as subgenus Eudesmia in the sense of Pryor and Johnson, partly as a convenience pending adequate resolution of relationships at this level. The various monophyletic units within the group are treated as sections.

\section{Terminology}

Terminology and nomenclature is as in previous papers in this series (see Hill \& Johnson 1995). The names applied to series and subseries by earlier authors are cited below merely to indicate the way in which those authors grouped the species concerned. Nothing is implied about their standing, since we are using only our extracodical system between genus and species. Names of sections, series and subseries (but not of subgenera or of species and subspecies) used by us are intentionally published in a system devised by Pryor \& Johnson (1971) and external to the International Code of Botanical Nomenclature. This avoids the confusion created by formal recognition of 'series' and 'subseries' used by Maiden (1903-1933) in a loose and informal sense, and classifying according to particular organ sets rather than as taxa. Moreover, as explained previously by Pryor \& Johnson (1971), it allows for clear

† Deceased 1 August 1997. 
application of names and categories. Since it has a perfectly clear formalism of its own, the term 'extracodical', rather than 'informal', is appropriate. Subseries names here differ from those used by Pryor \& Johnson in ending with '-osae'. This is because '-inae', as previously used, is a subtribal ending (International Code of Botanical Nomenclature, 1994, Art. 19.3).

Rare or threatened species are allocated conservation status codes according to the system of Briggs \& Leigh (1996).

The hairs on juvenile leaves of some taxa in subgenus Eudesmia are described as 'stellate hairs' for brevity. These are not stellate hairs as occurring in, for example, certain Chenopodiaceae, but distinctive structures in which a number of simple hairs arise from a raised oil gland (discussed by Johnson (1972) and Ladiges (1984)). They are also different in detail from superficially similar structures appearing in the bloodwoods (Hill \& Johnson 1996) and the stringybarks (Ladiges \& Humphries 1986). The comparable structures in the latter two groups are clearly apomorphic within those groups, and one hypothesis is that the structures in Eudesmia are also synapomorphic.

\section{Taxonomic history}

Brown (1814) described the genus Eudesmia R. Br. for the single species E. tetragona R. Br. Subsequent authors have generally submerged Eudesmia in Eucalyptus. A group of species was recognised as subseries Eudesmiae by Bentham (1867), including E. tetragona and other taxa corresponding to section Quadraria of Pryor \& Johnson (Bentham placed E. miniata and E. phoenicea in separate, widely differing groups with many other unrelated taxa).

Mueller (1882) placed all species of section Quadraria and most of Apicaria into the much more inclusive section Parallelantherae. The exception was E. baileyana, which he placed in section Renantherae, being misled by mixed material that included Eucalyptus tindaliae Blakely.

Maiden (Crit. Revis. Eucalyptus 6) placed the six Quadraria species then known with most of Apicaria (E. baileyana, together with E. similis and E. lirata which had by then been described) into a group Eudesmiae (三 subseries, in section Macrantherae subsection Longiores series Non-corymbosae). He placed E. miniata and E. phoenicea together, in the same section and subsection as Eudesmiae, in an anomalous un-named subseries in series Corymbosae. Blakely (1934) grouped the species as Maiden did, but ranked them as series Eudesmiae and series Miniatae, both in section Macrantherae.

Chippendale (1988) placed the species included in subgenus Eudesmia sensu Pryor \& Johnson into seven series, corresponding to Pryor \& Johnson groups at various ranks but with no indication of hierarchical relationships among the somewhat heterogeneous 'series' (or indeed among the 92 highly heterogeneous 'series' taken to comprise the genus Eucalyptus sens. lat.).

\section{Present classification}

Subgenus Eudesmia is here applied in the same sense as in Pryor \& Johnson's original circumscription (1971). Although some studies suggest that this group may be paraphyletic (Ladiges \& Humphries 1983), our earlier studies (Hill \& Johnson 1995) indicate that this is not necessarily the case. Our findings are supported to some extent by subsequent morphological and molecular studies by others than ourselves (Ladiges 
et al. 1995). The degree of morphological homoplasy at this level, however, renders morphology alone inadequate in resolving relationships, and very few characters are informative and unequivocal. A simple cladistic analysis of the characters useful in separating species and species groups at this level (listed in Table 1) clearly illustrates the inadequacy of these characters in resolving phylogenetic relationships (Fig. 1). Similarly, molecular studies reported to date do not clearly resolve relationships within Eudesmia (Ladiges et al., op. cit.).

The free or partially free calyx segments separate the eudesmioid group, together with E. microcorys, from the remainder of Eucalyptus sens. strict. Analyses (cited above) of the eucalypt groups indicate that the free persistent calyx is an ancestral condition, and thus that the free or partially free calyx condition is of no grouping value at this level (see Drinnan \& Ladiges 1989a \& b for discussion of the partial fusion of calyx and corolla). Floral development with fasciculate stamens is also indicated to be an ancestral condition and likewise a shared plesiomorphic state. The development of a stemonophore from the staminal buttress (Drinnan \& Ladiges 1989a \& b, 1991) is apomorphic for the entire Eucalyptus sens. strict. clade except E. curtisii, and does not help resolve relationships at the base of this clade.

Possession of eudesmioid hairs can be viewed as a strong and distinctive synapomorphic character uniting the three sections Quadraria, Xeraria and Apicaria. If this is so, inflorescence structure must be regarded as highly flexible within Eudesmia and of limited use in defining groups. The partial fusion of the calyx with the corolla evident in Apicaria, Xeraria and part of Quadraria is most parsimoniously viewed as an independent development to the calycine fusion seen in the remainder of Eucalyptus, possibly arising more than once within the eudesmioid group. The presence of oil glands in bark is also equivocal but in one possible interpretation this is a synapomorphy for Eudesmia and independently derived elsewhere in Eucalyptus. Another equivocal condition is the opposite adult leaves occurring in some groups. This may represent neotenous retention i.e. a secondary loss of the disjunct adult condition, or may genuinely represent a plesiomorphic state such as occurs in Allosyncarpia.

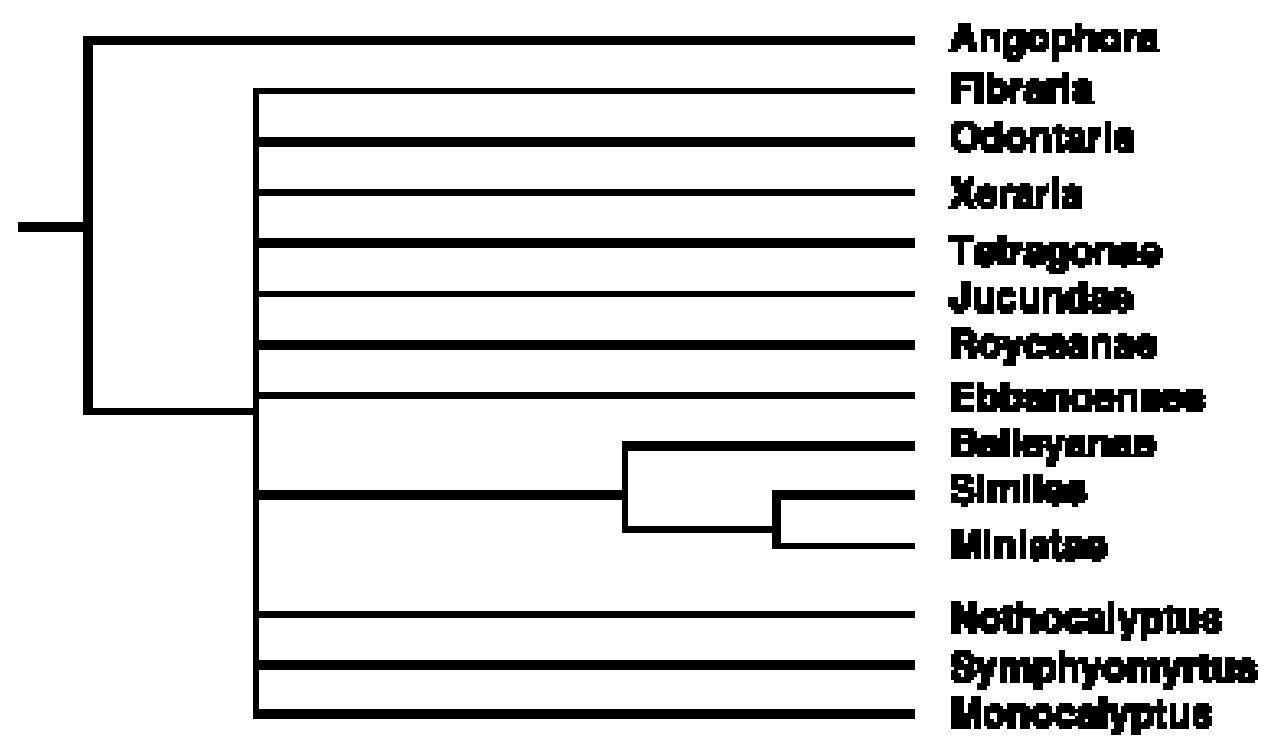

Fig. 1. Consensus cladogram from data as presented in Table 1 (generated from 93 equally parsimonious trees, length $=32$ steps, consistency index $=0.42$ ). Analysed using Hennig86 (Farris 1988). 
Table 1. Characters defining subgenus Eudesmia and constituent groups

\section{Character \\ 1. Habit \\ 2. Long fibrous bark \\ 3. 'Micaceous' bark \\ 4. Bark glands \\ 5. Eudesmioid hairs \\ 6. Juvenile leaves \\ 7. Juvenile leaves \\ 8. Adult leaves \\ 9. Inflorescences \\ 10. Calyx \\ 11. Calyx \\ 12. Stamens \\ 13. Flowers \\ 14. Staminal buttress}

\section{0}

mallee

absent

absent

absent

absent

sessile

opposite

opposite

not simple axillary

umbellasters

free

persistent

present

white

absent
1

tree

present

present

present

present

petiolate

disjunct

disjunct

simple axillary

umbellasters

partially fused

deciduous

stamens continuous

yellow or orange

present

$\begin{array}{llll}\text { Odontocarpae } & 10000 & 11110 & 0101 \\ \text { Gongylocarpae } & 00011 & 11101 & 1001 \\ \text { Eudesmiae } & 10011 & 11100 & 0101 \\ \text { Tetragonae } & 10011 & 01100 & 0111 \\ \text { Erythrocorythosae } & 10001 & 01100 & 0111 \\ \text { Ebbanonses } & 10011 & 00001 & 1101 \\ \text { Jucundae } & 10011 & 01111 & 1101 \\ \text { Royceanae } & 10011 & 01111 & 1101 \\ \text { Fibridia } & 01010 & 00000 & 0101 \\ \text { Similosae } & 01111 & 00001 & 1001 \\ \text { Baileyanosae } & 01111 & 00001 & 1101 \\ \text { Miniatosae } & 01111 & 00001 & 1011 \\ \text { Nothocalyptus } & 01100 & 01110 & 0001 \\ \text { Angophora } & 00000 & 10000 & 0100 \\ \text { Symphyomyrtus } & 00000 & 01111 & 1001\end{array}$

The largest species group is the south-western Australian section Quadraria, with some 11 species in 4 series. Inflorescence, calyx and bark characters mentioned above are flexible within the section, and the only uniform character is possession of eudesmioid hairs. The mallee habit is universal in this section (although present elsewhere in Eucalyptus), and can be viewed as an independent development also uniting the section. 
E. gongylocarpa, E. odontocarpa and E. gamophylla were included in a clade and referred to by Hill \& Johnson (l.c.) as Odontocalyptus. However, no clear apomorphies unite this clade, and it is here treated as two separate sections, Xeraria and Odontaria. Xeraria shares eudesmioid hairs as a synapomorphy with section Quadraria as treated here, and Odontaria shares the mallee habit with section Quadraria.

Pryor \& Johnson's section Apicaria, comprising two series, Miniatae and Baileyanae, is clearly monophyletic, defined as below, and shares eudesmioid hairs as a synapomorphy with sections Xeraria and Quadraria. Apicaria and the generally very different series Jucundae of Eudesmia sens. str. have somewhat similar bud morphology (Drinnan \& Ladiges 1989a), but we consider this a case of homoplasy. These two together are referred to as 'Eudesmia B' by Carr \& Carr $(1963,1968)$ and Drinnan \& Ladiges (1989a). Bark characters (see below) can be regarded as synapomorphic for this section.

The remaining species in the subgenus, E. tetrodonta, is a taxonomically isolated entity here placed in a monospecific section (see Table 2 for a summary of the classification proposed herein). It does not possess eudesmioid hairs, and thus does not share any clear and unique synapomorphies with the above sections. Oil glands in the bark occur in all sections except Odontaria, and may be synapomorphic, although similar glands occur sporadically in other eucalypt groups.

\section{Taxonomic treatment}

Eucalyptus subgenus Eudesmia (R. Br.) L.A.S. Johnson E K.D. Hill, stat. nov.

三Eudesmia R. Br., Appendix Flinders Voyage 2: 599, t. 3 (1814).

Type species: E. tetragona R. Br., 1.c.

Trees or mallees; bark smooth, sometimes with more or less persistent ribbons or ribbony flakes; or partly or wholly persistent and long-fibrous. Oil glands often present in bark. Radiating, unicellular, blunt-ended thin-walled trichomes arising from flat or slightly prominent glands present on juvenile leaves and shoots, except in sections Fibraria and Odontaria. Juvenile leaves opposite for few to many nodes. Adult leaves disjunct or sometimes opposite, glabrous; tertiary and higher-order venation of reticulum often much reduced. Conflorescences lateral, anthotelic or anauxotelic, panicles, thyrsoids or metabotryoids, or more often reduced to, or consisting of leafy shoots bearing, 3- or 7-flowered umbellasters, these rarely plurinodate or of condensed metabotryoid form, sometimes with accessory branching (superposed). Perianth 4-merous (fixed); carpels 3(-4). Calyx of free reduced persistent sepals, or more or less fused with the corolla in section Apicaria and series Ebbanoenses, Jucundae and Royceanae. Corolla calyptriform, but junctions of petals often discernible. Stamens all fertile, often in $4 \pm$ clearly discernible bundles; filaments white, cream, yellow, yellow-green or orange; anthers dorsifixed, versatile, oval, dehiscing by curved divergent or almost parallel slits. Style short (not reaching calypra in bud) and straight, or long (touching calyptra in bud) and bent. Stigma blunt or tapered, lobed, with short unicellular papillae (long and multicellular in E. erythrocorys). Ovules hemitropous, arranged in 2 separated vertical rows or 4 or 6 vertical rows in each loculus. Seed testa derived from inner and outer integument. Cotyledons emarginate, reniform, not folded in embryo. Seed variable in shape, sometimes keeled or narrowly winged; hilum always ventral. Fruit woody, sometimes 4 -winged or with 4 sepaline teeth; capsule usually sunken with valves enclosed. 
Table 2. A classification of subgenus Eudesmia

Subgenus Eudesmia

Section Xeraria

Section Odontaria

$$
\text { E. gongylocarpa }
$$

$$
\begin{aligned}
& \text { E. odontocarpa } \\
& \text { E. gamophylla }
\end{aligned}
$$

Section Quadraria

Series Tetragonae

Subseries Eudesmioideosae

E. eudesmioides

E. pallida

E. selachiana

Subseries Tetragonosae

$$
\begin{aligned}
& \text { E. gittinsii } \\
& \text { E. conveniens } \\
& \text { E. eyreana } \\
& \text { E. tetragona }
\end{aligned}
$$

Subseries Erythrocorythosae

E. erythrocorys

Series Jucundae

$$
\text { E. jucunda }
$$

Series Royceanae

$$
\text { E. roycei }
$$

Series Ebbanoenses

$$
\text { E. ebbanoensis }
$$

subsp. photina subsp. ebbanoensis subsp. glauciramula

Section Fibraria

$$
\text { E. tetrodonta }
$$

Section Apicaria

Series Baileyanae

$$
\text { E. baileyana }
$$

Series Similes

$$
\begin{aligned}
& \text { E. similis } \\
& \text { E. lirata }
\end{aligned}
$$

Series Miniatae

Subseries Miniatosae

$$
\begin{aligned}
& \text { E. miniata } \\
& \text { E. gigantangion }
\end{aligned}
$$

Subseries Phoeniceosae

E. phoenicea

E. ceracea 


\section{Key to species}

1 Inflorescences not simple axillary triads

2 Unit inflorescences compound or aggregated into branched terminal or axillary conflorescences

3 Calyx persistent as 4 small teeth at top of hypanthium

4 Adult leaves glossy, lanceolate, petiolate, disjunct

2. E. odontocarpa

$4^{*}$ Adult leaves dull, elliptical, subsessile, opposite

3. E. gamophylla

$3^{*}$ Calyx partially fused to corolla and shed at anthesis

5 Buds not square, not glaucous

12. E. jucunda

$5^{*}$ Buds square, glaucous

13. E. roycei

2* Unit inflorescences simple, axillary, 7- or more flowered

6 Inflorescences more than 11-flowered

21. E. phoenicea

$6 *$ Inflorescences not more than 11-flowered

7 Adult leaves opposite, sessile

22. E. ceracea

$7^{*}$ Adult leaves not opposite or sessile

8 Bark wholly smooth.

1. E. gongylocarpa

$8^{*}$ Bark not wholly smooth

9 Bark fully persistent

18. E. baileyana

9* Bark not fully persistent

10 Adult leaves lanceolate; fruits ovoid

19. E. miniata

$10^{*}$ Adult leaves narrow-lanceolate; fruits urceolate

20. E. gigantangion

$1^{*}$ Inflorescences simple axillary triads

11 Calyx difficult to discern

12 Bark smooth throughout

14. E. ebbanoensis

$12 *$ Bark not smooth throughout

13 Peduncles 20-30 mm long 17. E. similis

13* Peduncles 7-10 mm long 16. E. lirata

$11^{*}$ Calyx reduced, free, evident as 2 or 4 small teeth on rim of hypanthium

14 Calyptra red 11. E. erythrocorys

$14^{*}$ Calyptra not red

15 Mature adult leaves, buds and fruits pruinose with a loose, waxy coating 16 Adult leaves less than $18 \mathrm{~mm}$ wide 5. E. pallida $16^{*}$ Adult leaves commonly more than $20 \mathrm{~mm}$ wide

17 Adult leaves lanceolate 8. E. conveniens $17^{*}$ Adult leaves elliptical 10. E. pleurocarpa 
$15^{*}$ Mature adult leaves, buds and fruits not pruinose

18 Trees 15. E. tetrodonta

$18^{*}$ Mallees

19 Pedicels less than $5 \mathrm{~mm}$ long

20 Adult leaves dull

4. E. eudesmioides

$20^{*}$ Adult leaves glossy

6. E. selachiana

19* Pedicels more than $5 \mathrm{~mm}$ long

21 Fruits $12 \mathrm{~mm}$ diam. or less

7. E. gittinsii

$21^{*}$ Fruits $13 \mathrm{~mm}$ diam. or more

9. E. tetragona

\section{Section Xeraria}

This and the following section were combined and treated as Series Odontocarpae Chippendale (1988). Chippendale's name is not part of our extracodical system.

Bark smooth, with oil glands. Juvenile growth glabrous or hispid with radiating hairs; juvenile leaves opposite, sessile. Adult leaves opposite or subopposite. Conflorescence axillary, compound; with unit umbellasters 3-flowered, or simple, axillary, 7-flowered. Calyx reduced, persistent as teeth at top of hypanthium. Stamens in 4 bundles; filaments white or cream.

The sectional name refers to the occurrence of the single constituent species in arid regions.

1. Eucalyptus gongylocarpa Blakely, Trans. \& Proc. Roy. Soc. South Australia 60: 153 (1936).

Type: Western Australia: Camp 60, vicinity of Victoria Spring, Victoria Desert, R. Helms s.n., 24 Sep 1891 (holo NSW, cannot be found).

Tree to $15 \mathrm{~m}$. Bark smooth, white to pale grey or cream, often with scattered thin adherent scales. Twigs and stems glaucous. Juvenile leaves to $5 \mathrm{~cm}$ long and $3.5 \mathrm{~cm}$ wide, opposite, sessile, ovate to orbiculate, cordate, apically rounded, with 'stellate hairs'. Adult leaves $4-7 \mathrm{~cm}$ long, $0.8-1.4 \mathrm{~cm}$ wide, opposite or sub-opposite, lanceolate to narrow-elliptical, apiculate, glabrous, mid-green, dull, glaucous; petioles 3-10 mm long; lateral veins at c. $30-40^{\circ}$ to midrib, moderately closely spaced; secondary reticulum incomplete; intramarginal vein irregular, c. $1 \mathrm{~mm}$ from leaf margin. Inflorescences simple, axillary; unit umbellasters 7-flowered; peduncles terete, 8-19 $\mathrm{mm}$ long; pedicels terete, $2-5 \mathrm{~mm}$ long. Mature buds clavate, glaucous, $3-5 \mathrm{~mm}$ long, 3-4 mm diam.; calyx free, persistent as 4 small teeth around top of hypanthium on mature fruits; calyptra shallowly hemispherical, $1 / 3-1 / 2$ as long as hypanthium. Stamens all fertile, in 4 fascicles; filaments regularly inflexed; anthers oblong, versatile, dehiscing through parallel slits. Fruits 3-4-locular, globular, markedly constricted apically, 6-10 mm long, 6-10 mm diam.; disc 1-3 mm wide, steeply depressed; valves deeply enclosed. Seeds dorsiventrally flattened, dull, black, with a narrow translucent wing around the edge; hilum ventral; chaff angular, dark brown.

Distribution: centred on the Victoria Desert (Fig. 2), in the region bounded by the George Gill Range (north-east), Vokes Hill (south-east), Plumridge Lakes (south-west), Sandstone (west) and Kumarina (north-west).

Ecology: a locally abundant species dominating open savanna woodlands on deep red aeolian sand deposits, with an understorey dominated by Triodia. 
Conservation status: not considered to be at risk.

Selected specimens (from 40 examined): Northern Territory: $231 / 2$ miles [37.8 km] S of George Gill Range, Chippendale, 27 June 1959 (DNA, NSW); 3 miles [4.8 km] E of Lake Amadeus, Dunlop 1891, 21 Sep 1970 (DNA, NSW); Dean Range, 4 miles [6.4 km] W of Docker Settlement, Dunlop 1937, 6 Oct 1970 (DNA, NSW); 15 miles [24.2 km] Ayers Rock, Dunlop 2035, 6 Nov 1970 (DNA, NSW).

South Australia: $4 \mathrm{~km} \mathrm{~W}$ of Vokes Hill junction, $258 \mathrm{~km}$ from Cook, Great Victoria Desert, Alcock 8144, 22 Aug 1980 (AD, CANB, DNA, NSW, NY, PRE); $195.5 \mathrm{~km}$ N of Cook towards Vokes Junction, Brooker 9423, 28 Aug 1986 (CANB, NSW); c. $130 \mathrm{~km} \mathrm{~W}$ of Emu along Vokes Hill track, Lothian 5641, 18 July 1972 (AD, CANB, NSW); 43 miles [69.2 km] SE of Chestermans Peak road junction, Symon 2604, 6 Aug 1962 (AD, NSW); Great Victoria Desert, Connie Sue Highway \pm 6 km W of Vokes Hill Junction, Symon 12427, 22 Aug 1980 (AD, CANB, K, DNA, NSW).

Western Australia: 20.2 miles [32.5 km] NW of Agnew, towards Sandstone, Baker 100, 19 Nov 1970 (CANB, NSW); between Cashmere Downs and Bulga Downs, Beard 6494, 9 Sep 1973 (PERTH, NSW); $42.6 \mathrm{~km}$ N of Wiluna towards Cunyu, Brooker 10722, 16 Apr 1991 (CANB, AD, DNA, NSW, PERTH); 22 miles [35.4 km] east of Cosmo Newberry, Carolin 5915, 27 July 1967 (NSW); 20 km WNW along track from S end of Plumridge Lakes, Crisp 5801, 14 Sep 1979 (CANB, NSW, PERTH); 31 miles [49.6 km] NE of Laverton, George 8688, 12 July 1967 (PERTH, NSW); $10.7 \mathrm{~km} \mathrm{~N}$ of Kumarina roadhouse on Great Northern Highway, Hill 500 Johnson Blaxell \& Brooker, 2 Nov 1983 (NSW, CANB, PERTH); 16 miles [25.8 km] NE of Millrose Homestead, Eremean Province, Speck 1387, 8 Sep 1958 (CANB, NSW).

\section{Section Odontaria}

This and the previous section were combined and treated as Series Odontocarpae Chippendale (1988). Chippendale's name is not part of our extracodical system.

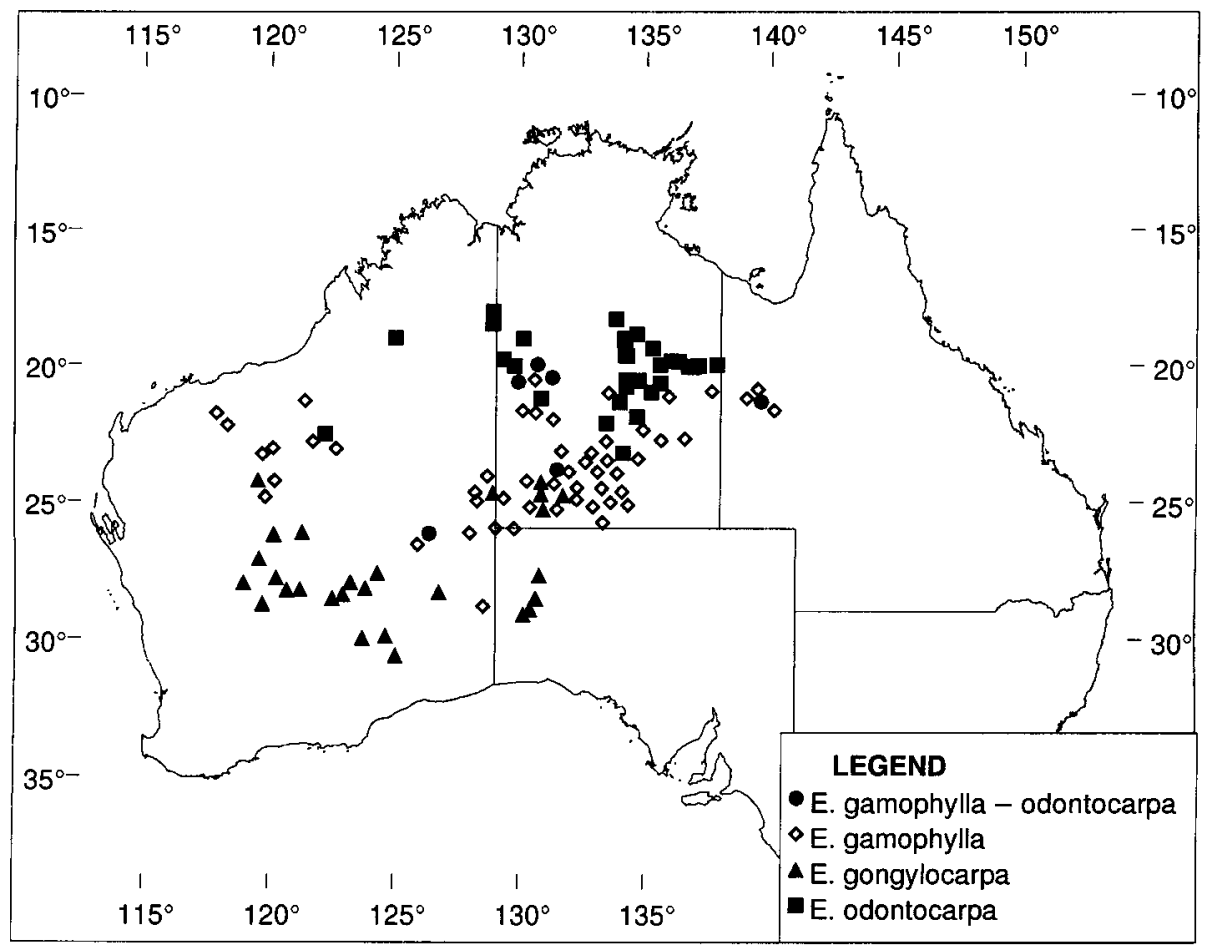

Fig. 2. Distribution of E. odontocarpa, E. gamophylla, E. gongylocarpa. 
Mallees. Bark smooth, without oil glands. Juvenile growth glabrous or hispid with radiating hairs; juvenile leaves opposite, often connate, sessile, glabrous. Adult leaves opposite or subopposite. Conflorescence axillary, often compound; with regular unit umbellasters 3-flowered. Calyx free, reduced, persistent as teeth at top of hypanthium. Stamens in 4 bundles; filaments white or cream.

Connation of juvenile leaves, when present, is always a later development and does not occur in the earliest juvenile leaves.

A section with two closely allied species.

2. Eucalyptus odontocarpa F. Muell., J. Linn. Soc., Bot. 3, 98 (1859).

Type: Sturt's Ck., F. Mueller s.n. (holo MEL).

Mallee to $4 \mathrm{~m}$. Bark smooth, white to grey, cream or pinkish. Twigs and stems not or very weakly pruinose. Juvenile leaves to $10 \mathrm{~cm}$ long and $2.5 \mathrm{~cm}$ wide, opposite, sessile, elliptical to lanceolate, cordate or sometimes connate, apically rounded to acute, glabrous. Adult leaves $6-12 \mathrm{~cm}$ long, $0.7-1.5 \mathrm{~cm}$ wide, sub-opposite to disjunct, narrow-lanceolate to lanceolate, acuminate, glabrous, mid-green, glossy, not pruinose; petioles 3-10 $\mathrm{mm}$ long; lateral veins at c. $30-45^{\circ}$ to midrib, moderately closely spaced; secondary reticulum incomplete; intramarginal vein irregular, $1-2.5 \mathrm{~mm}$ from leaf margin. Inflorescences compound and terminal or simple and axillary; unit umbellasters simple, 3-flowered; peduncles terete or angular, 2-5 mm long; pedicels terete, 1-3 mm long. Mature buds clavate, not pruinose, 4-6 mm long, 3-4 mm diam.; calyx free, persistent as 4 small teeth around top of hypanthium on mature fruits; calyptra shallowly hemispherical, $1 / 3-1 / 2$ as long as hypanthium. Stamens all fertile, in 4 fascicles; filaments regularly inflexed; anthers oblong, versatile, dehiscing through parallel slits. Fruits 3-locular, cylindrical or barrel-shaped, slightly constricted apically, 4-angled, 8-11 mm long, 5-6 mm diam.; disc 1-2 mm wide, steeply depressed; valves deeply enclosed. Seeds dorsiventrally flattened, dull, greyish black, with a narrow translucent wing around the edge; hilum ventral; chaff angular, dark brown.

Hybrids and intergrades with E. gamophylla have been recorded.

Distribution: Rudall River region in Western Australia east to south-west of Mt Isa in Queensland (Fig. 2).

Ecology: a mallee species in desert shrublands, usually on red sandy soils or sometimes on low stony rises with Triodia understorey.

Conservation status: not considered to be at risk.

Selected specimens (from 54 examined): Northern Territory: $9.4 \mathrm{~km} \mathrm{~W}$ of Stuart highway on Anningie road, Brooker 5125, 7 Apr 1976 (CANB, NSW); Alyawarr Desert, $135 \mathrm{~km} \mathrm{~W}$ of Camooweal, Brooker 11565, 22 Sep 1993 (CANB, BRI, DNA, NSW); 10 miles [16 km] NW of Tanami on road to Billiluna and Halls Creek, Carolin 7926, 23 Aug 1970 (SYD, NSW); 58 miles [92.8 km] S Hookers [Hooker] Creek, Chippendale, 14 July 1956 (DNA, NSW); 8.6 miles [13.8 km] W of Soudan homestead, Chippendale E Johnson, 2 Oct 1957 (DNA, NSW); Central Mt Stuart, Chippendale, 18 July 1958 (DNA, NSW); 11.6 km N of Wauchope on Stuart Highway, Hill 877 Johnson \& Benson, 12 July 1984 (NSW, CANB, DNA, PERTH); 14.6 km N of Tennant Ck, Puttock 11113 \& Waterhouse, 17 July 1980 (UNSW, DNA, NSW).

Western Australia: desert S of Fitzroy River, North Kimberly, Fitzgerald, Sep 1906 (NSW); 5 miles [8 km] SE of Swindells Field, Great Sandy Desert, George 9150, 31 July 1967 (PERTH, NSW); $2.7 \mathrm{~km} \mathrm{~W}$ of Nicholson rd junction, Hill 1002 Johnson \& Benson, 3 Aug 1984 (NSW, CANB, DNA, PERTH); Rudall River area, Maslin 2124, 5 Sep 1971 (PERTH, NSW); 20 miles [32 km] S of Nicholson station, Perry 2372, 6 July 1949 (CANB, NSW). 


\section{E. gamophylla-E. odontocarpa intergrades}

Selected specimens (from 8 examined): Queensland: $79 \mathrm{~km} \mathrm{SW}$ of Mt Isa (1.5 km N of Urandangi turn-off), Harris 602, 603, 7 May 1990 (NSW).

Western Australia: 60 km SW of Warburton on road to Laverton, Briggs 3538 a, 12 June 1970 (NSW).

Northern Territory: 10 miles [16.1 km] E The Granites, Chippendale, 4 May 1958 (DNA, NSW); 6 miles [9.7 km] NW of The Granites Township, Lazarides 6257, 22 Apr 1957 (CANB, NSW); 64 miles [103.0 km] SE Mongrel Downs Homestead, Maconochie 1041, 26 May 1970 (DNA, NSW); near EM3 Well, Mereenie Oil Field, Weston 13434, 9 Mar 1983 (DNA, NSW).

3. Eucalyptus gamophylla F. Muell., Fragm. 11:40 (1878).

Type: Western Australia: Mount Pyrten, Hamersley Range, J. Forrest (holo MEL).

Mallee to $7 \mathrm{~m}$. Bark smooth, white to grey, cream or pinkish, sometimes with a short persistent stocking on the lower trunk of larger individuals. Twigs and stems glaucous. Juvenile leaves to $10 \mathrm{~cm}$ long and $0.6 \mathrm{~cm}$ wide, opposite, sessile, ovate to elliptical, cordate or connate, apically rounded or apiculate, glabrous. Adult leaves $6-8 \mathrm{~cm}$ long, $0.9-1.5 \mathrm{~cm}$ wide, opposite, sessile, elliptical or ovate to lanceolate, rounded or apiculate, glabrous, mid-green, dull, glaucous; lateral veins at c. $30-45^{\circ}$ to midrib, moderately closely spaced; secondary reticulum incomplete; intramarginal vein irregular, 1-2 mm from leaf margin. Inflorescences compound and terminal or simple and axillary; unit umbellasters simple, 3-flowered; peduncles terete or angular, 3-8 mm long; pedicels terete, 1-4 mm long. Mature buds clavate or pyriform, glaucous, $4-6 \mathrm{~mm}$ long, 3-4 mm diam.; calyx free, persistent as 4 small teeth around top of hypanthium on mature fruits; calyptra shallowly hemispherical, $1 / 4-1 / 3$ as long as hypanthium. Stamens all fertile, in 4 fascicles; filaments regularly inflexed; anthers oblong, versatile, dehiscing through parallel slits. Fruits 3-locular, cylindrical or barrel-shaped, slightly constricted apically, 4-angled, 6-10 mm long, 5-6 mm diam.; disc 1-2 mm wide, steeply depressed; valves deeply enclosed. Seeds dorsiventrally flattened, dull, greyish black, with a narrow translucent wing around the edge; hilum ventral; chaff angular, dark brown.

Hybridisation with E. odontocarpa (q.v.) is known.

Distribution: from near Tom Price in the Pilbara region of Western Australia east to south-west of Mt Isa in Queensland (Fig. 2).

Ecology: a component of mallee shrublands on red desert dunes with Triodia understorey.

Conservation status: not considered to be at risk.

Selected specimens (from 97 examined): Northern Territory: c. 8 km SSE of Fiddlers Lake; Sangsters Bore area, Albrecht 6207, 16 June 1994 (NT, DNA, NSW); 41 miles [65.6 km] from Yuendumu Mt Doreen road, Carolin 7940, 24 Aug 1970 (SYD, NSW); 52 miles [83.2 km] W Hermannsburg, Chippendale, 24 Aug 1956 (DNA, NSW); 9.6 miles [15.4 km] N of Georgina Downs, Chippendale \& Johnson, 1 Oct 1957 (DNA, NSW); 4.5 miles [7.2 km] E Lasseters Cave, Petermann Range area, Chippendale, 24 June 1958 (DNA, NSW); 18.5 miles [29.6 km] N Lake Amadeus, Chippendale, 28 June 1959 (DNA, NSW); 28 km W of Curtin Springs on Ayers Rock rd, Hill 853, 10 July 1984 (NSW, CANB, DNA, PERTH); 48 miles [76.8 km] ENE of Harts Range Police Depot, Lazarides 5215, 8 May 1955 (CANB, NSW); 3 miles [4.8 km] NW of The Granites Township, Lazarides 6258, 22 Apr 1957 (CANB, NSW); 118 miles 188.8 km] W Ayers Rock, Maconochie 747, 18 Sep 1969 (DNA, NSW); Uluru (Ayers Rock - Mt Olga) National Park, on Docker River rd, 33.5 km WNW of Ranger Station, Palmer 150 \& Lazarides, 16 May 1988 (CANB, NSW); near gate to radio station at Heavitree Gap near Alice Springs, Stocker 532, 17 June 1970 (CANB, NSW).

Queensland: Oban station, 60 miles [96 km] SW of Mt Isa, Everist 1701, 30 Nov 1938 (BRI, NSW); 89.7 miles [135.5 km] from Mt Isa towards Dajarra, Hall H74/58, 5 July 1974 (CANB, NSW); 56 km S of Mt Isa, Harris 420, 29 July 1989 (BRI, NSW); Yappo Creek, 53 km S of Mt Isa, Harris 601, 28 Apr 1990 (NSW, BRI). 
South Australia: Boundary of South \& Western Australia, Helms s.n., 17 July 1891 (NSW); Mann Range, Milthorpe 3099, 3 Nov 1974 (NSW).

Western Australia: S end Schwerin Mural Crescent, Carolin 6204, 2 Aug 1967 (NSW); Wittenoon Gorge, above the old asbestos mine, Croat 52288 A, 6 Aug 1981 (MO, NSW); 6 km S of Moffita Well campsite, along vermin fence, Fensom 361 \& Wilson, 29 July 1995 (NSW); 60 miles [96 km] SW of Warburton Mission, George 8168, 30 Sep 1966 (PERTH, NSW); S of Rudall River, George 10736, 20 May 1971 (PERTH, NSW); $83.6 \mathrm{~km} \mathrm{~W}$ of Wittenoom on track to Millstream, Hill 435 Johnson Blaxell Brooker \& Edgecombe, 30 Oct 1983 (NSW, AD, CANB, K, MEL, PERTH); 10.7 km N of Kumarina roadhouse on Great Northern Hwy, Hill 501 Johnson Blaxell \& Brooker, 2 Nov 1983 (NSW, CANB, PERTH); Gibson Range, c. 200 km E of Walgun on Lake Disappointment rd, Pryor, 21 Aug 1985 (NSW); 3 miles [4.8 km] S of the Sir Fredrick Range, Symon 2283, 1 Aug 1962 (AD, NSW); $39.5 \mathrm{~km}$ along road to Telfer; edge of Great Sandy Desert, Wilson 939 \& Rowe, 5 Sep 1991 (NSW, CANB, PERTH)

\section{Section Quadraria}

Bark smooth, with or without oil glands. Radiating hairs present on juvenile growth. Juvenile leaves petiolate or sessile, opposite or disjunct. Adult leaves opposite or disjunct. Conflorescence axillary, compound; with unit umbellasters 3-7-flowered, or of simple axillary triads (3-flowered umbellasters). Calyx reduced, persistent as teeth at top of hypanthium, or as teeth on apex of calyptra. Stamens continuous or in 4 bundles; filaments white, cream or yellow.

\section{Key to series}

1. Calyx free, persistent series Tetragonae

$1 *$ Calyx more or less fused to corolla, shedding as part of calyptra

2 Inflorescences simple axillary triads series Ebbanoenses

2* Inflorescences compound, 7-9-flowered

3 Calyx wholly fused to corolla series Jucundae

$3^{*}$ Calyx irregularly partially fused to corolla. series Royceanae

\section{Series Tetragonae}

Treated as Series Heteroptera Maiden by Chippendale (1988), with 4 species included. As we have indicated previously, these names attributed to Maiden are classifications of organ-sets and not taxa, and are not acceptable under the ICBN. They are not part of our extracodical system.

Inflorescences consisting of simple, axillary triads (3-flowered umbellasters). Calyx reduced, persistant as teeth at top of hypanthium. Stamens in 4 bundles (with few intermediate stamens in E. erythrocorys); filaments white, cream or yellow.

A series of eight species in three subseries, showing wide diversity in form. All species are western Australian, the group ranging from the Shark Bay district south and then east to around Israelite Bay. Constituent species are mainly found on sandy soils, and do not extend into drier areas of the eastern Wheat Belt or Goldfields. 


\section{Key to subseries}

1 Calyptra and hypanthium similar in colour; oil glands present in bark; filaments white to yellow; stigmatic papillae short; disc sharply depressed in fruit

2 Juvenile leaves sessile; filaments white or cream subseries Eudesmioidosae

2* Juvenile leaves petiolate; filaments cream to yellowish .... subseries Tetragonosae

$1^{*}$ Calyptra markedly different to hypanthium in colour; oil glands not present in bark; filaments yellow-green; stigmatic papillae long; disc level or raised in fruit subseries Erythrocorythosae

\section{Subseries Eudesmioidosae}

Juvenile leaves opposite, sessile. Adult leaves opposite or subopposite. Oil glands present in bark. Calyptra and hypanthium similar in colour. Filaments white or cream. Stigmatic papillae short. Disc steeply depressed in fruit.

A subseries made up of three species.

4. Eucalyptus eudesmioides F. Muell., Fragm. 2: 35 (1860); as E. eudesmoides.

Type: Western Australia: Murchison R., N of Mt Curious, A. Oldfield (holo MEL, iso K).

We regard the original spelling as an unintentional orthographic error, since the epithet clearly referred to Eudesmia.

= Eucalyptus eudesmioides F. Muell. var. globosa Blakely, Key Eucalypts, 69 (1934).

Type: Western Australia: Mingenew, J.H. Maiden, Oct 1909 (holo NSW). Pryor \& Johnson (1971) regarded this supposed taxon as not distinct from the type variety; we agree with this.

[Eudesmia eucalyptoides F. Muell., Fragm. 2: 35 (1860), nom. invalid., in syn. sub Eucalyptus eudesmioides F. Muell.]

Burbidge (1947) and Black (1952) used the name E. eudesmioides for the taxon now known to be E. gongylocarpa, as stated by Jessop (1986: 909).

Mallee to $6 \mathrm{~m}$, usually less than $4 \mathrm{~m}$. Bark smooth, white to grey, cream or pinkish, sometimes with a short persistent stocking on the lower trunk of larger individuals. Twigs and stems not or very weakly pruinose. Juvenile leaves to $7 \mathrm{~cm}$ long and $4 \mathrm{~cm}$ wide, opposite, sessile, elliptical, becoming ovate, cordate, apically rounded, with 'stellate hairs'. Adult leaves 3-10 cm long, 0.7-2.0 cm wide, opposite, lanceolate, acuminate, somewhat dorsiventral, glabrous, dull, not pruinose; petioles 5-13 mm long; lateral veins at c. $30-45^{\circ}$ to midrib, moderately closely spaced; secondary reticulum incomplete; intramarginal vein irregular, c. $1 \mathrm{~mm}$ from leaf margin. Umbellasters simple, axillary, 3-flowered; peduncles terete or angular, 5-13 mm long; pedicels terete, 5-9 $\mathrm{mm}$ long. Mature buds clavate, not pruinose, 5-7 mm long, 3-5 mm diam.; calyx free, persistent as 4 small teeth around top of hypanthium on mature fruits. Stamens all fertile, in 4 fascicles; filaments regularly inflexed; anthers oblong, versatile, dehiscing through parallel slits. Fruits 3-locular, truncate-pyriform, slightly constricted apically, vaguely 4-angled, 10-15 mm long, 8-10 mm diam.; disc 1-1.5 mm wide, moderately depressed; valves enclosed, reduced, papery. Seeds irregular, angular, dull, brownish black, with a ragged translucent wing around the edge; hilum ventral; chaff angular, dark brown (Fig. 3 e,f).

E. eudesmioides is distinguished within the series by the small, lanceolate to broadlanceolate, opposite, dull greyish but not pruinose adult leaves. 
Intergrading populations with E. gittinsii are known.

Distribution: Murchison River south to near Mogumber, near-coastal in the north, but running inland south of the latitude of Three Springs (Fig. 4).

Ecology: locally frequent on sandy soils on sandplain over laterite, or on shallow sandy residuals over laterite.

Conservation status: not considered to be at risk. Well represented in conservation areas.

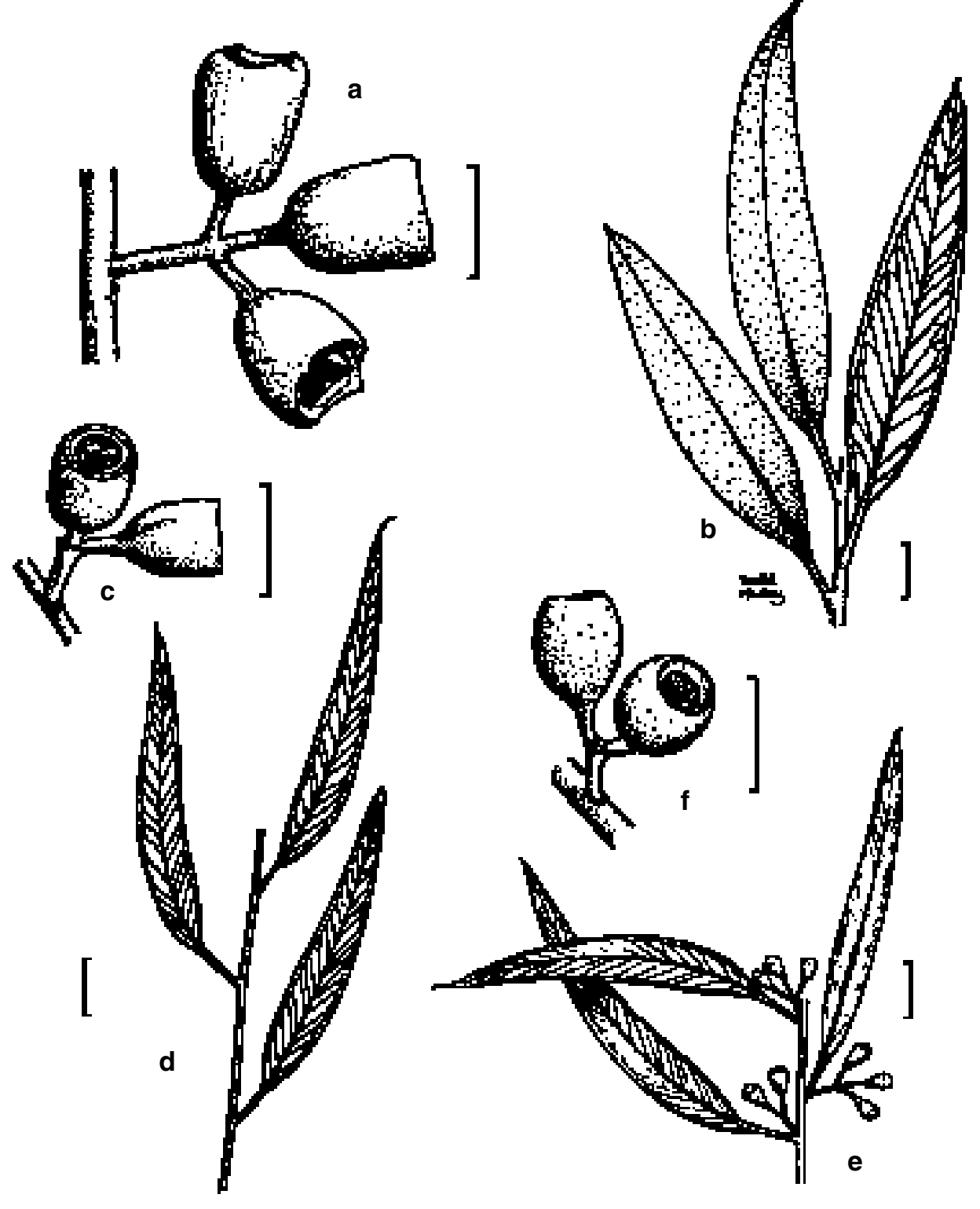

Fig. 3. E. selachiana: a, fruits, b, adult leaves (from Brooker 8129); E. pallida: c, fruits d, adult leaves (from Blaxell 1981 et al.); E. eudesmioides: e, buds and adult leaves, f, fruits (e from Brooker 9194, $\mathrm{f}$ from Melville 4209). Scale bar $=1 \mathrm{~cm}$. 
Selected specimens (from 53 examined): Western Australia: 2.5 [4 km] miles N of Murchison River on Coastal Highway, Beard 6717, 7 Oct 1973 (PERTH, NSW); $10 \mathrm{~km}$ NW of Three Springs, B. Briggs 7750 E Johnson, 1 Oct 1984 (NSW, PERTH); Babilion Range, N of Mogumber, Brooker 8524, 23 Apr 1984 (CANB, NSW, PERTH); Nanson road, Brooker 9194, 12 Mar 1985 (CANB, NSW); 29.6 miles [48 km] E of Geraldton, Chippendale 45, 20 Oct 1966 (CANB, NSW); 8.3 miles [c. $13 \mathrm{~km}$ ] N of Watheroo, Chippendale 316, 15 Mar 1968 (CANB, NSW); Mingenew, Fitzgerald, Sep 1903 (PERTH, NSW); 6 miles [10 km] SW of Mullewa, Melville 4209 \& Calaby, 20 July 1953 (K, NSW); 1 mile [1.6 km] inland from Kalbarri, Phillips CBG 39718, 19 Sep 1968 (CANB, NSW); 14.3 miles [c. 23 km] S of Carnamah, Tindale 1282, 28 Mar 1970 (NSW, K, PERTH).

\section{E. eudesmioides-E. gittinsii intergrades}

Selected specimens (from 9 examined): Western Australia: $15.8 \mathrm{~km} \mathrm{~W}$ of Three Springs on Eneabba Road, Blaxell 1996 \& Johnson, 28 May 1983 (NSW, AD, CANB, PERTH); $31 \mathrm{~km} \mathrm{~W}$ of Three Springs, W end of Nebru Road at junction with Moorlaby Road, Briggs 7520 E Johnson, 30 Sep 1984 (NSW, CANB, PERTH); Burma Road Nature Reserve, north side fence-line, Brooker 7942, 26 Jan 1983 (CANB, NSW); 11 km SE of Badgingarra on Moora road, Wilson 2707 a, 2 Oct 1979 (NSW).

\section{Eucalyptus pallida L.A.S. Johnson E K.D. Hill, sp. nov.}

Affinis E. eudesmioidei sed characteribus sequentibus distinguitur: ramuli dense albo incerati, fructus plerumque minores et folia angustiora petiolis longioribus.

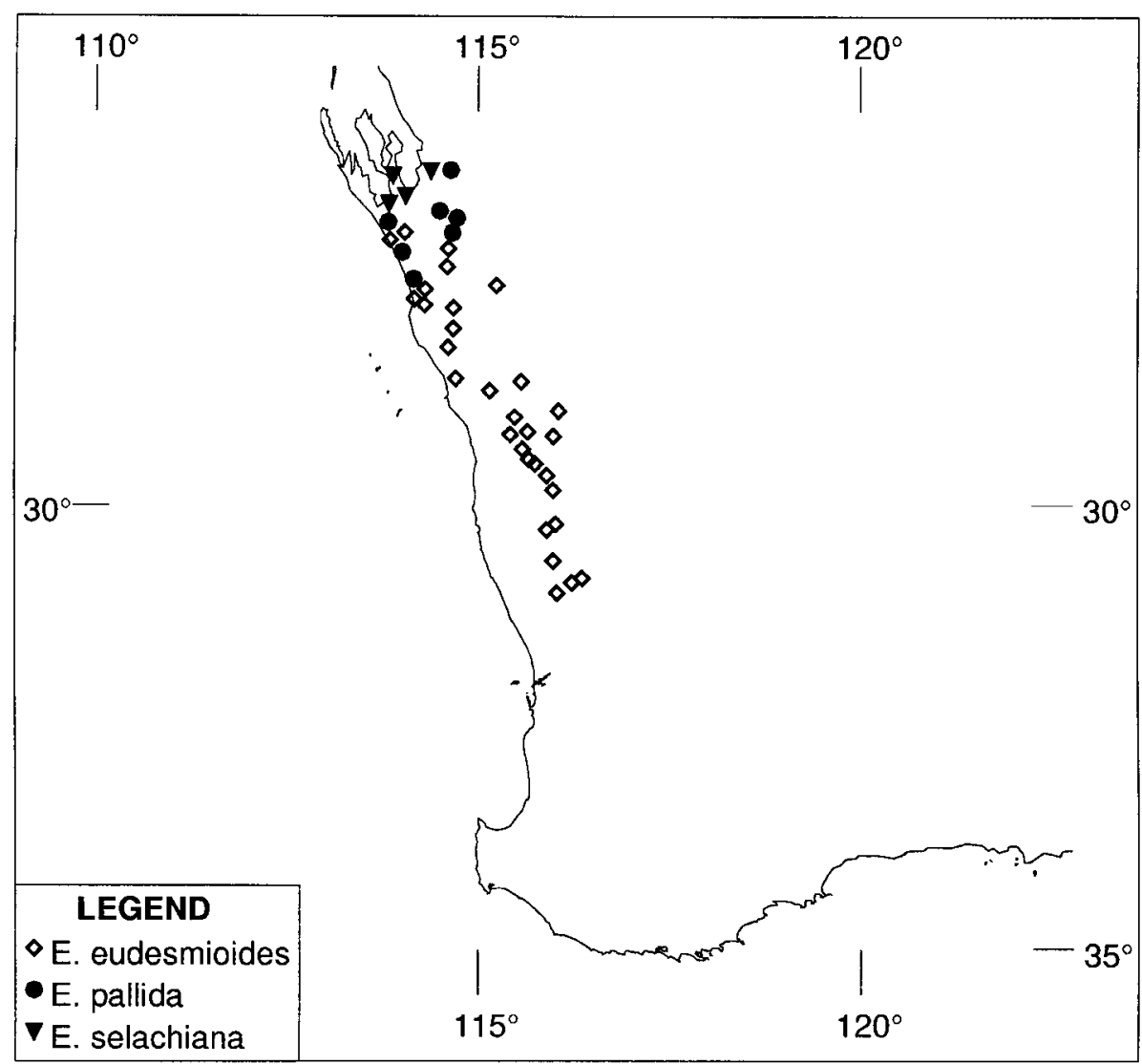

Fig. 4. Distribution of E. pallida, E. selachiana, E. eudesmioides. 
Type: Western Australia: $8 \mathrm{~km}$ N of Wannoo on highway $\left(26^{\circ} 49^{\prime} \mathrm{S}, 114^{\circ} 37^{\prime} \mathrm{E}\right)$, D. Blaxell 1981, L. Johnson, I. Brooker, S. Hopper, 26 May 1983 (holo NSW; iso CANB, MEL, PERTH).

Mallee to $8 \mathrm{~m}$. Bark coarsely fibrous-flaky, light grey to about $2 \mathrm{~m}$, smooth, white above. Twigs and stems strongly pruinose. Juvenile leaves $1.5-2.5 \mathrm{~cm}$ long, $1-1.5 \mathrm{~cm}$ wide, opposite, sessile, ovate to elliptic, cordate, apically rounded, with 'stellate hairs'. Adult leaves $4.5-10 \mathrm{~cm}$ long, $0.9-1.6 \mathrm{~cm}$ wide, opposite, lanceolate, acuminate, slightly dorsiventral, glabrous, dull, pruinose; petioles 5-9 mm long; lateral veins at c. $30-45^{\circ}$ to midrib, moderately closely spaced; secondary reticulum incomplete; intramarginal vein irregular, c. $1 \mathrm{~mm}$ from leaf margin. Umbellasters simple, axillary, usually 3-flowered; peduncles terete, 4-9 $\mathrm{mm}$ long; pedicels terete, 2-5 $\mathrm{mm}$ long. Mature buds pruinose, clavate; calyx free, persistent as 4 small teeth around top of hypanthium on mature fruits. Stamens all fertile, in 4 fascicles; filaments regularly inflexed; anthers oblong, versatile, dehiscing through parallel slits. Fruits 3-locular, truncate-pyriform, slightly constricted apically, vaguely 4-sided, 8-10 mm long, 5-7 mm diam.; disc 1-1.5 mm wide, moderately depressed; valves enclosed, reduced, papery. Seeds irregular, angular, dull, brownish black, with a ragged translucent wing around the edge, hilum ventral, 2-4 mm long, 1.5-3 mm wide; chaff angular, dark brown, $1 \mathrm{~mm}$ long (Fig. $3 \mathrm{c}$, d).

E. pallida differs from E. eudesmioides in the dense white waxy coating on the stems, the generally smaller fruits, and the narrower leaves with longer petioles. It is also frequently a larger plant, consistently with a short stocking of persistent bark on the lower trunks. This taxon is referred to as the 'northern pallid subspecies' of E. eudesmioides by Brooker \& Kleinig (1990). It does not intergrade with E. eudesmioides or E. selachiana (below).

Distribution: restricted to a small area north-east of Kalbarri and south-east of Hamelin Pool (Fig. 4).

Ecology: locally frequent on red aeolian sandhill country, of less coastal facies than that carrying E. selachiana.

Conservation status: not considered to be at risk. Although restricted in distribution, this species is common in remote areas that are unlikely to be disturbed.

The specific epithet is from the Latin pallidus, pale, referring to the light colour of the wax-covered branchlets.

Selected specimens (from 13 examined): Western Australia: $34 \mathrm{~km} \mathrm{E} \mathrm{of} \mathrm{'Woodleigh'} \mathrm{homestead,}$ Brooker 8640, 29 Aug 1984 (CANB, NSW, PERTH); 150 miles [240 km] S of Carnarvon, Olsen 558, 3 Aug 1967 (NSW).

\section{Eucalyptus selachiana L.A.S. Johnson \& K.D. Hill, sp. nov.}

Affinis E. eudesmioidei sed characteribus sequentibus distinguitur: folia latiora nitidaque et fructus majores.

Type: Western Australia: Useless Loop road (263'ㅇ, $\left.114^{\circ} 03^{\prime} \mathrm{E}\right)$, M.I.H. Brooker 8129 , 26 May 1983 (holo NSW; iso CANB, PERTH).

Mallee to $3 \mathrm{~m}$. Bark smooth, pale bronze and white. Adult leaves $6-8 \mathrm{~cm}$ long, $1.2-1.8 \mathrm{~cm}$ wide, opposite, lanceolate to broad-lanceolate, slightly dorsiventral, glabrous, markedly glossy, dark green; petioles $7-16 \mathrm{~mm}$ long; lateral veins at $30-40^{\circ}$ to midrib, moderately closely spaced; secondary reticulum irregular and incomplete; intramarginal vein distinct, looped between lateral veins, $1.0-2.5 \mathrm{~mm}$ from leaf margin, usually with some reticulation between vein and margin. Umbellasters simple, axillary, 3-flowered; peduncles terete, 5-7 mm long; pedicels terete, 3-5 mm long. Calyx free, persisting as 4 small teeth around top of hypanthium on mature fruits. Stamens all fertile, in 4 fascicles; filaments regularly inflexed; anthers oblong, 
versatile, dehiscing through parallel slits. Fruits 3-locular, truncate-pyriform to cylindrical, apically constricted, vaguely 4-sided, 11-14 mm long, 9-11 mm diam.; disc 1.5-2.5 mm wide, moderately depressed; valves enclosed. Seeds irregular, angular, dull, brownish black, with a ragged translucent wing around the edge; hilum ventral; chaff angular, dark brown (Fig. 3 a,b).

E. selachiana differs from E. eudesmioides in the broader, glossy green leaves and the larger fruits. This taxon is referred to as the 'northern glossy subspecies' of E. eudesmioides by Brooker \& Kleinig (1990).

Distribution: known only from a small area immediately to the south-east of Shark Bay (Fig. 4).

Ecology: locally frequent in subcoastal scleromorphic communities on calcareous red aeolian sand, sometimes with subsurface calcrete, with E. roycei D. Carr, S. Carr \& A.S. George and E. mannensis subsp. vespertina L.A.S. Johnson \& K.D. Hill.

Conservation status: $2 \mathrm{R}$. Although restricted, this species occurs in a remote area which is not likely to be disturbed.

The specific epithet is from the neo-Latin zoological group name Selachii, sharks and related fishes, ultimately from the Greek selachos, a shark or similar fish, in reference to the species' occurrence near Shark Bay. The 'ch' is pronounced hard, as in 'chemistry'.

Selected specimens (from 7 examined): Western Australia: 'Tamala' station road, off Shark Bay road, Blaxell 1983, Johnson, Brooker \& Hopper, 26 May 1983 (NSW); c. 22 km N of 'Overlander' roadhouse, Boomsma 334A, 28 June 1978 (AD, NSW).

\section{Subseries Tetragonosae}

Juvenile leaves opposite, petiolate. Oil glands present in bark. Calyptra and hypanthium similar in colour. Stigmatic papillae short. Filaments cream to yellowish. Disc steeply depressed in fruit.

Four species are included in the subseries.

7. Eucalyptus gittinsii Brooker \& Blaxell, Nuytsia 2(4): 228, Fig. 5 (1978).

Type: Western Australia: 67 km S of 'Billabong Roadhouse', Wannoo, Highway 1 (273'ㄴ, $114^{\circ} 45^{\prime}$ E), D.F. Blaxell W75/113, 9 Oct 1975 (holo NSW; iso CANB, K, PERTH).

Mallee to $5 \mathrm{~m}$. Bark smooth, grey-brown, sometimes with a persistent stocking on the lower trunk of larger individuals. Young shoots angular, not pruinose. Juvenile leaves elliptical to ovate, to $9 \mathrm{~cm}$ long, $4 \mathrm{~cm}$ wide, petiolate, dull greyish, becoming broadlanceolate, to $15 \mathrm{~cm}$ long, $6 \mathrm{~cm}$ wide. Adult leaves 7-14 cm long, 1.2-3 cm wide, coriaceous, lanceolate, acuminate, glossy or sub-glossy, not pruinose, green to yellowgreen, sub-opposite to disjunct; petioles narrowly flattened, 10-24 $\mathrm{mm}$ long; lateral veins at $30-40^{\circ}$ to midrib, moderately closely spaced; secondary reticulum irregular and incomplete; intramarginal vein distinct, looped between lateral veins. Inflorescences simple, axillary; umbellasters 3-flowered; peduncles 5-18 mm long; pedicels 5-12 mm long, both narrowly 2-winged. Buds not pruinose, clavate, 5-8 mm long, 4-6 mm diam.; calyptra about $1 / 4-1 / 3$ as long as hypanthium, shallowly hemispherical. Calyx free, persisting as 4 small teeth around top of hypanthium on mature fruits. Stamens all fertile, in 4 fascicles; filaments regularly inflexed; anthers oblong, versatile, dehiscing through parallel slits. Fruits ovoid to elongate-ovoid, often narrowly 2-winged or ridged, 12-20 mm long, 8-12 mm diam., 4-locular; disc vertically depressed. Seeds irregular, angular, dull, dark brownish black, with a ragged translucent wing around the edge; hilum ventral; chaff angular, dark brown. 
E. gittinsii is distinguished within the series by the often disjunct, green to yellowgreen, generally more or less glossy leaves, the lack of pruinosity, and the medium to large leaves, buds and fruits. E. selachiana has similar glossy, non-pruinose leaves, but these are opposite and smaller, and buds and fruits are smaller.

Distribution: apparently disjunct, with one area of occurrence around the Murchison River and north to the type locality, and the other from the Greenough River south to near Mogumber (Fig. 5).

Ecology: locally frequent in tall mallee shrub-heath communities on deep red aeolian sand deposits in the north of the range, in lower shrub heath on shallow sandplains or skeletal sands over laterite in the south.

Conservation status: not considered to be at risk. Locally frequent and wellrepresented in conserved areas.

Selected specimens (from 32 examined): Western Australia: Hawkshead Lookout, Kalbarri Natl Park, Bedford 587, 31 Oct 1985 (NSW, CANB, PERTH); 9 km NW of Three Springs, B. Briggs 7748 $\mathcal{E}$ Johnson, 1 Oct 1984 (NSW, PERTH); $7 \mathrm{~km} \mathrm{~W}$ of Brand Highway on Cadda Road to Cervantes, Brooker 7928, 24 Jan 1983 (CANB, NSW, PERTH); Burma Road Nature Reserve, north side fence line, Brooker 7942, 26 Jan 1983 (CANB, NSW, PERTH); 2 km W of Brand Highway on Green Head Road, Crisp 5415, 24 Jan 1979 (CANB, NSW, PERTH); Babilion Hills, near Mogumber, Gardner 1886, 20 Dec 1922 (PERTH, NSW); 41 miles [65 km] S of Wannoo roadhouse, Gittins 1562, Aug 1967 (NSW); NW slope of Mt Michaud, Hill 2949, 29 Aug 1988 (NSW).

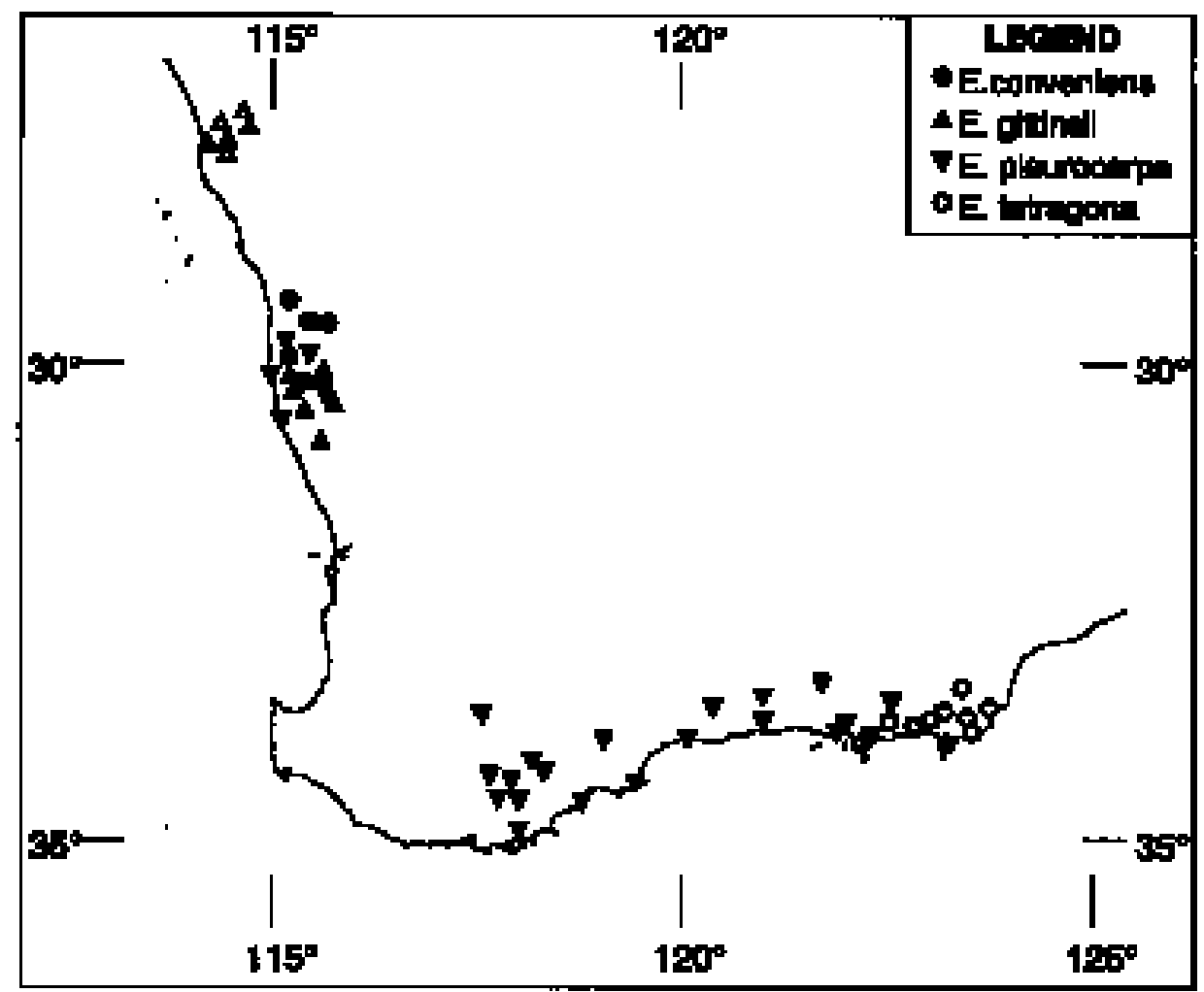

Fig. 5. Distribution of E. tetragona, E. pleurocarpa, E. conveniens and E. gittinsii. 


\section{Eucalyptus conveniens L.A.S. Johnson $\mathcal{E}$ K.D. Hill, sp. nov.}

$\mathrm{Ab}$ E. tetragona fructibus minoribus et foliis minoribus proportione angustioribus, $\mathrm{ab}$ E. gittinsii foliis non nitentibus sed glaucis vel pruinosis, distinguitur.

Type: Western Australia: Moorlaby Road 22 km S of Midlands Highway, B.G. Briggs 2506 E L.A.S. Johnson, 30 Sep 1984 (holo NSW; iso AD, CANB, PERTH).

\section{[Eucalyptus sp. A of Brooker \& Kleinig (1990)]}

Mallee to $2.5 \mathrm{~m}$. Bark smooth, grey-brown. Young shoots angular, pruinose. Leaves, buds and fruits often pruinose. Juvenile leaves to $9 \mathrm{~cm}$ long, $5 \mathrm{~cm}$ wide, ovate, petiolate. Adult leaves $6-12 \mathrm{~cm}$ long, $1.5-3.5 \mathrm{~cm}$ wide, coriaceous, broad-lanceolate to ovate, opposite to subopposite, acute to apiculate, dull grey-green, pruinose; petioles broadly flattened, $15-30 \mathrm{~mm}$ long; lateral veins at 30-40 to midrib, moderately closely spaced; secondary reticulum irregular and incomplete; intramarginal vein distinct, looped between lateral veins. Inflorescences simple, axillary; umbellasters 3-flowered; peduncles 6-11 mm long; pedicels 4-7 mm long, both narrowly 2-winged. Buds pruinose, clavate, 7-8 $\mathrm{mm}$ long, 5-6 $\mathrm{mm}$ diam.; calyptra about half as long as hypanthium, hemispherical. Calyx free, persisting as 4 small teeth around top of hypanthium on mature fruits. Stamens all fertile, in 4 fascicles; filaments regularly inflexed; anthers oblong, versatile, dehiscing through parallel slits. Fruits ovoid to elongate-ovoid, often narrowly 2-winged or ridged, 10-18 mm long, 8-11 mm diam., 4-locular; disc vertically depressed. Seeds irregular, angular, dull, dark brownish black, with a ragged translucent wing around the edge; hilum ventral; chaff angular, dark brown (Fig. 6).

E. conveniens is distinguished from E. pleurocarpa Schauer by the smaller buds and fruits (buds to $10 \mathrm{~mm}$ long, $8 \mathrm{~mm}$ diam., fruits to $25 \mathrm{~mm}$ long, $22 \mathrm{~mm}$ diam. in E. pleurocarpa), and the smaller and proportionately narrower leaves. E. conveniens differs from E. tetragona s. orig. et stricto (distinguished below from E. pleurocarpa) in the smaller, narrower leaves, the shorter pedicels and peduncles, and the smaller buds and fruits. It usually retains more pruinosity, seldom seen in E. tetragona except on very young shoots.

This taxon has been regarded as a hybrid between E. pleurocarpa and E. gittinsii Brooker \& Blaxell, but closer field examination shows that considerable uniform populations exist. These may have originated as hybrids, but, if so, are now stable and self-sustaining, and hence may be recognised as a species. It seems just as likely that E. conveniens is essentially a northern equivalent of E tetragona. E. gittinsii differs in the glossier leaves and lack of pruinosity.

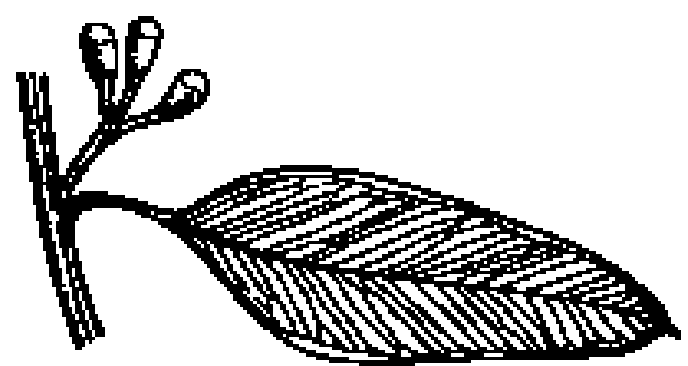

a

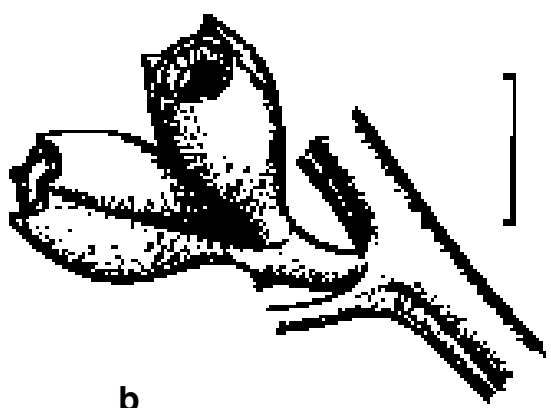

b

Fig. 6. E. conveniens. a, adult leaves and buds. b, fruits (a from Brooker 7950, b from Brooker 7204). 
Distribution: restricted to the west coast of Western Australia, from around Mt Adams south to near Badgingarra (Fig. 5).

Ecology: locally frequent in mallee heath communities on sand plains.

Conservation status: not considered to be at risk. Locally frequent and wellrepresented in conserved areas.

The epithet is from the Latin conveniens, coming together, in reference to its somewhat intermediate position between E. tetragona and E. gittinsii.

Selected specimens (from 11 examined): Western Australia: Mt Adams Nature Reserve, Blaxell 1983, Johnson, Brooker \& Hopper, 28 May 1983 (NSW, CANB, PERTH); $36.1 \mathrm{~km} \mathrm{~N}$ of hill River crossing on highway, Brooker 7204, 17 Nov 1981 (CANB, NSW, PERTH); 'Hivalley Farm', Tootbardi Road, N of Badgingarra, Brooker 7651, 21 Sep 1982 (CANB, NSW, PERTH); opposite proposed Mt Adams Nature Reserve, eastern side, Brooker 7950, 26 Jan 1983 (CANB, NSW, PERTH); c. 15 km from Three Springs on Eneabba road, Hill 2559, Johnson, Blaxell \& Brooker, 21 Nov 1986 (NSW, PERTH).

9. Eucalyptus tetragona (R. Br.) F. Muell., Fragm. 4: 51 (1864).

三Eudesmia tetragona R. Br., Appendix Flinders Voyage, 2:599 (1814), t. 3.

Type: Western Australia: Lucky Bay, R. Brown (Bennett 4807), 13 Jan 1802 (holo BM; iso $\mathrm{K})$. Although the type is from an area where intergradation between E. tetragona and E. pleurocarpa is known, the leaf, fruit, pedicel and peduncle shape and dimensions, together with the lack of any mention of marked pruinosity of stems, buds or fruits place it clearly with the eastern taxon.

[Eucalyptus sp. B of Brooker \& Kleinig (1990)]

Mallee to $2 \mathrm{~m}$, usually less than $1.5 \mathrm{~m}$, often procumbent. Bark smooth, grey-brown. Young shoots quadrangular, often glaucous or pruinose. Juvenile leaves to $10 \mathrm{~cm}$ long and $6 \mathrm{~cm}$ wide, opposite, elliptical to ovate. Adult leaves $6-14 \mathrm{~cm}$ long, $2.5-5 \mathrm{~cm}$ wide, opposite, coriaceous, broad-lanceolate to ovate, acute to apiculate, dull green; petioles 15-30 mm long; lateral veins at $30-40^{\circ}$ to midrib, moderately closely spaced; secondary reticulum irregular and incomplete; intramarginal vein distinct, looped between lateral veins. Inflorescences simple, axillary; umbellasters 3-flowered; peduncles 15-20 mm long; pedicels 7-20 mm long, both narrowly 2-winged. Buds ovoid to clavate, nor pruinose, $8-10 \mathrm{~mm}$ long, 6-7 mm diam.; calyptra about half as long as hypanthium, hemispherical. Calyx free, persisting as 4 small teeth around top of hypanthium on mature fruits. Stamens all fertile, in 4 fascicles; filaments regularly inflexed; anthers oblong, versatile, dehiscing through parallel slits. Fruits ovoid, often narrowly 2- or 4-winged or ridged, 16-24 mm long, 13-18 mm diam., 4-locular; disc vertically depressed. Seeds irregular, angular, dull, brownish black, with a ragged translucent wing around the edge; hilum ventral; chaff angular, dark brown (Fig. 7).

E. tetragona is distinguished from E. pleurocarpa Schauer by the ovoid rather than globose fruits with generally longer pedicels and peduncles, the smaller and proportionally narrower leaves (leaves on mature plants of E. pleurocarpa are elliptical, to $13 \mathrm{~cm}$ long, $7 \mathrm{~cm}$ wide), and by the pruinosity being limited to very young growth. Mature adult leaves are consequently dull green rather than whitish- or bluish-grey.

Distribution: this species occurs on the south coast of Western Australia, from Lucky Bay to Israelite Bay, and possibly further east (Fig. 5).

Ecology: restricted to coastal heath communities on sand plains. This species occurs along the coast in country near Condingup, with E. pleurocarpa replacing it further inland. To the east of there, E. tetragona wholly replaces E. pleurocarpa. The intergradation found in contact areas is quite limited, but does occur near Lucky Bay.

Conservation status: not considered to be at risk. This species is abundant in several large national parks. 
Selected specimens (from 21 examined): Western Australia: 10 miles [16 km] NE of Condingup, Beard 6347, 16 Sep 1970 (PERTH, NSW); Lucky Bay, Cape le Grand National Park, Blaxell 1684, 22 June 1978 (NSW, CANB, PERTH); 2.5 km S of Tower Peak, Ragged Range, Crisp 4827, 6 Jan 1979 (CBG, CANB, NSW, PERTH); 300 metres E of old 'Hill Spring' homestead, SE Mt Arid, Hill 3164, 8 Sep 1988 (NSW); slopes of Mt Ragged, Powell 3489, Everett \& Bedford, 24 Nov 1985 (NSW, CANB, PERTH); 8.4 km W of Israelite Bay, Pryor E J. Briggs s.n., 26 Oct 1978 (NSW 340822); Boyatup Hill, Pullen 10087, 18 Dec 1984 (CANB, NSW, PERTH); between Hopetoun and E Mt Barren, Strid 21896, 2 Jan 1983 (NSW).

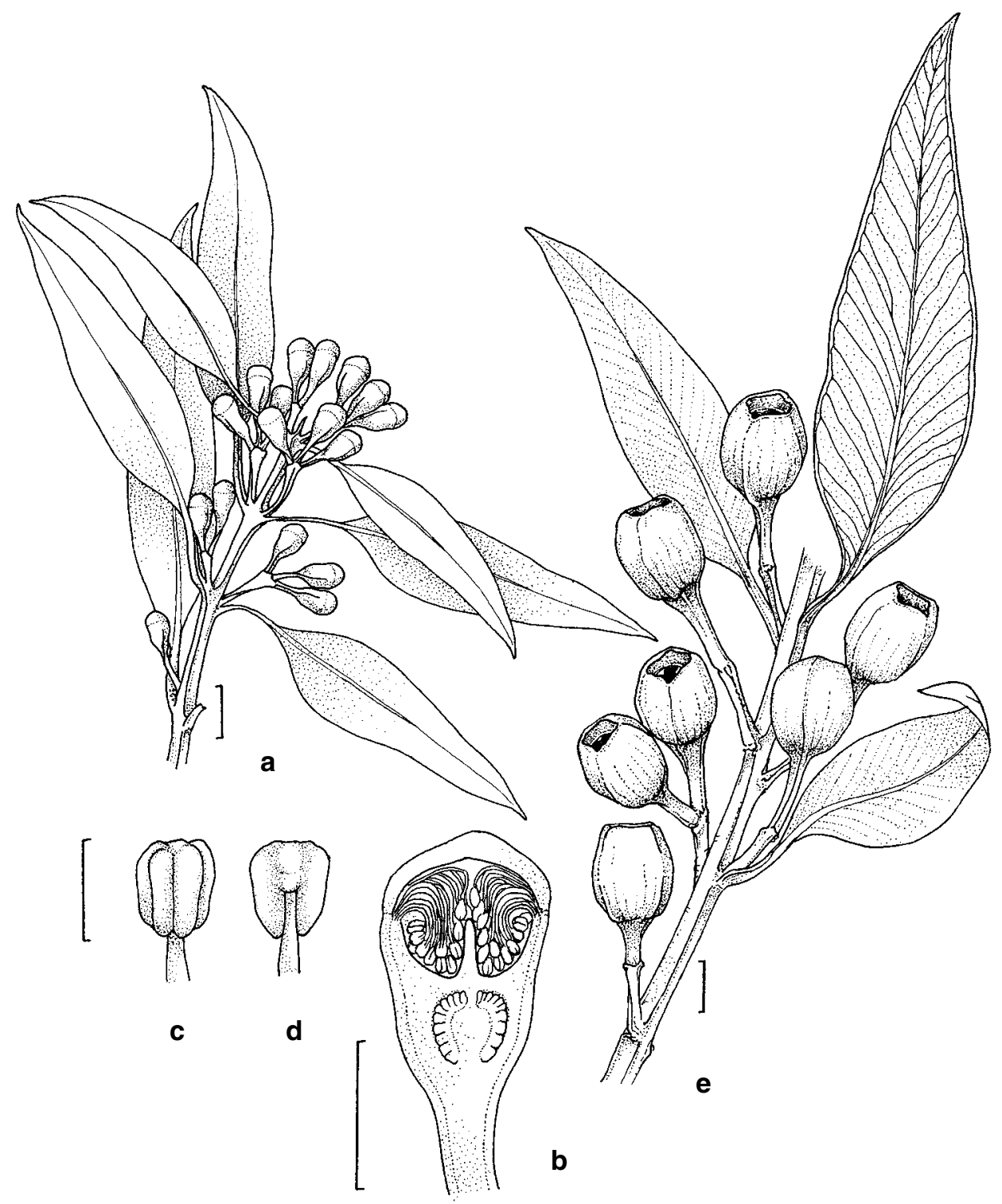

Fig. 7. E. tetragona. $\mathbf{a}$, adult leaves and buds. $\mathbf{b}$, transverse section of bud. $\mathbf{c}, \mathbf{d}$, anther. e, adult leaves and fruits (a, c, d, e from Crisp 4827, b from Pryor \& Briggs NSW 340822). Scale bar: a, e = $1 \mathrm{~cm}$; $\mathrm{b}=5 \mathrm{~mm} ; \mathrm{c}, \mathrm{d}=0.5 \mathrm{~mm}$. 
10. Eucalyptus pleurocarpa Schauer, in Lehm., Pl. Preiss. 1: 132 (1844).

Type: Cited as 'In glareosis sterilibus ad radices collium Konkoberup promontorii Cape Riche, Novembri a. 1840 fructifera. Herb. Preiss. No. 253.' Although this specimen has not been seen in the Preiss herbarium in recent times, we have studied populations corresponding with the protologue at the type locality, and have no doubt that they represent the common 'Tallerack' of the south-west.

Included in E. tetragona by Bentham (1867).

Mallee to $5 \mathrm{~m}$, usually with long erect trunks and small, bushy canopy. Bark smooth, grey to pale grey-brown or yellow-brown. Young shoots quadrangular, strongly pruinose. Juvenile leaves initially hairy, opposite, elliptical, becoming glabrous and similar to adult leaves. Adult leaves 5-13 cm long, 3-7 cm wide, opposite or subopposite, coriaceous, broadly elliptical, apiculate, dull grey and strongly pruinose; petioles broadly flattened, 7-20 mm long; lateral veins at $40-60^{\circ}$ to midrib, moderately closely spaced; secondary reticulum irregular and incomplete; intramarginal vein distinct, looped between lateral veins. Inflorescences simple, axillary; umbellasters 3-flowered; peduncles 5-15 mm long; pedicels 4-10 mm long, both 2-winged. Buds strongly pruinose, ovoid to clavate, $7-9 \mathrm{~mm}$ long, 5-7 mm diam.; calyptra about half as long as hypanthium, hemispherical. Calyx free, persisting as 4 small teeth around top of hypanthium on mature fruits. Stamens all fertile, in 4 fascicles; filaments regularly inflexed; anthers oblong, versatile, dehiscing by parallel slits. Fruits ovoid, often narrowly 2- or 4-winged or ridged, 13-24 mm long, 10-21 mm diam., 4-locular; disc vertically depressed. Seeds irregular, angular, dull, brownish black, with a ragged translucent wing around the edge; hilum ventral; chaff angular, dark brown (Fig. 8).

E. pleurocarpa is distinguished within the subseries by the globose fruits with short pedicels and peduncles, the ovate to elliptic adult leaves, and by the strong pruinosity on all parts.

Distribution: this species occurs in a zone from about Katanning south-east to Bremer Bay, and east to Lucky Bay, with an outlying northern population from about Eneabba to south of Badgingarra (Fig. 5). In the east, it runs somewhat inland around

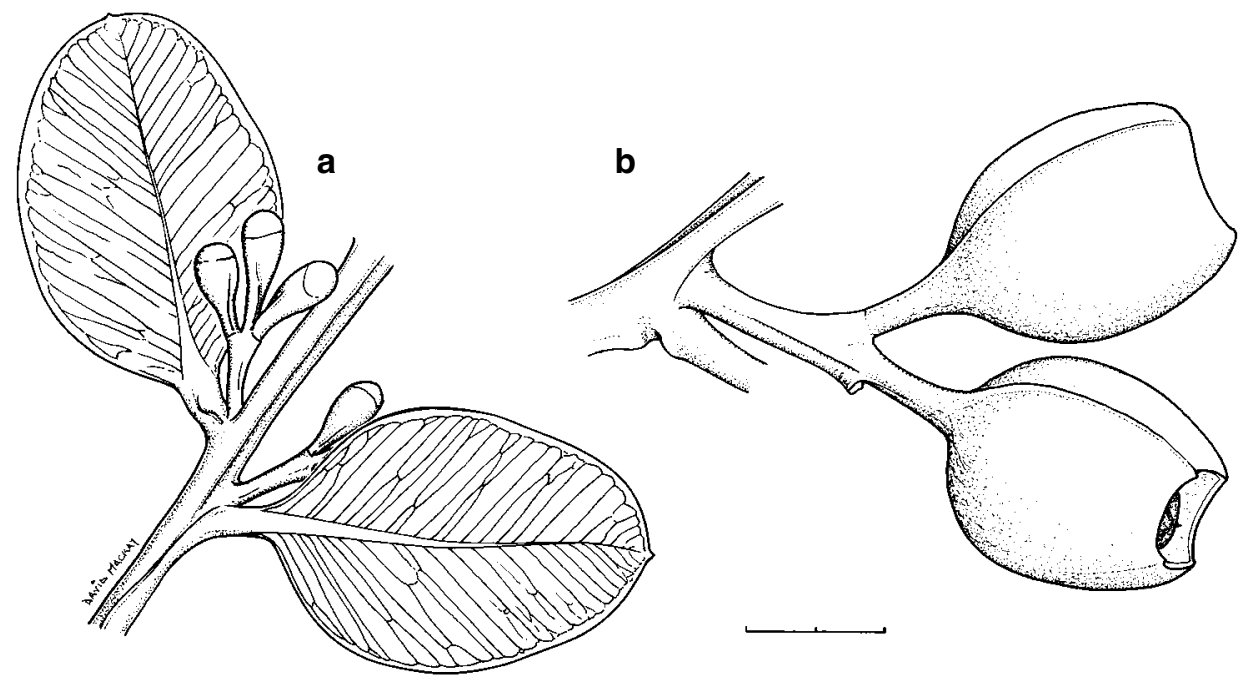

Fig. 8. E. pleurocarpa. a, adult leaves and buds. b, fruits (from Strid 21896). Scale bar $=1 \mathrm{~cm}$. 
Condingup, with E. tetragona replacing it along the coast. To the east of there, E. tetragona wholly replaces E. pleurocarpa. The intergradation found in contact areas is quite limited, but does occur near Lucky Bay.

Ecology: restricted to shrub-heath communities on grey or white sand plain country, often in lower areas or sites with slightly impeded drainage.

Conservation status: not considered to be at risk. This species is abundant in several large national parks.

Selected specimens (from 37 examined): Western Australia: $48 \mathrm{~km} \mathrm{~S}$ of Jurien Bay, Beadle 178, 9 Oct 1972 (NSW); c. $15 \mathrm{~km}$ E of Esperance on Cape Le Grand road, Blaxell 1680, 22 June 1978 (NSW); Brand Highway, $16 \mathrm{~km} \mathrm{~S}$ of Eneabba, B. Briggs 7722 \& Johnson, 30 Sp 1984 (NSW, PERTH); 22.3 miles [33 km] S of Salmon Gums, Chippendale 181, 13 Mar 1967 (CANB, NSW); 22.7 km NW of Muntz

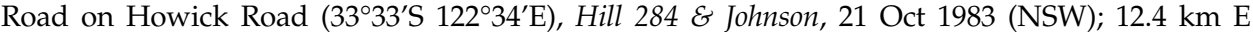
Amelup, on Sandalwood Road, Hill 2435, Johnson \& Blaxell, 12 Nov 1986 (NSW, PERTH); Mt Barker to Woogenellup, Johnson W82, 13 Dec 1960 (NSW); Katanning, Stoward, Sep 1914 (NSW); between Hopetoun and E Mount Barren, Strid 21896, 2 Jan 1983 (NSW); Bremer Bay, Thorne, Jan 1970 (NSW); $14.1 \mathrm{~km}$ SE of Jerdacuttup River crossing on Ravensthorpe-Esperance road, Tindale 3812, 29 Aug 1973 (NSW).

\section{Subseries Erythrocorythosae}

Bark smooth; lacking oil glands. Inflorescence simple, 3-flowered. Calyptra red, with prominent cruciform ridges. Filaments yellow-green. Stigmatic papillae long. Disc level or raised in fruit.

A monotypic subseries, related to but clearly distinct from the other subseries.

11. Eucalyptus erythrocorys F. Muell., Fragm. 2: 33 (1860).

Type: Western Australia: Murchison R., A. Oldfield s.n. (holo MEL; iso K).

[Eudesmia erythrocorys F. Muell., Fragm. 2: 33 (1860), nom. invalid., in syn. Eucalyptus erythrocorys]

Tree or stout few-stemmed mallee to $8 \mathrm{~m}$. Bark smooth, grey or cream to pale grey-brown; sometimes irregularly persistent in flaky patches. Juvenile leaves to $10 \mathrm{~cm}$ long and $5 \mathrm{~cm}$ wide, opposite, petiolate, ovate, green, densely hispid with 'stellate hairs'. Adult leaves 12-20 cm long, 1.2-3 cm wide, opposite or subopposite, coriaceous, narrow-lanceolate to lanceolate, acuminate, glossy, green; petioles 10-30 $\mathrm{mm}$ long; lateral veins at $30-40^{\circ}$ to midrib, moderately closely spaced; secondary reticulum irregular and incomplete; intramarginal vein distinct, looped between lateral veins. Inflorescences simple, axillary; umbellasters 3-flowered; peduncles 15-30 mm long; pedicels 5-10 mm long, both 2-winged. Buds broadly campanulate, 25-35 mm long, 15-25 mm diam.; calyptra about half as long as hypanthium, shallowly hemispherical, 4-lobed with cruciform ridging, red; hypanthium green. Calyx free, persisting as 4 small teeth around top of hypanthium on mature fruits. Stamens all fertile, in 4 fascicles; filaments regularly inflexed, yellow-green; anthers oblong, versatile, dehiscing by parallel slits. Fruits broadly campanulate, apically broadly 4-lobed, 25-45 mm long, 30-50 mm diam., 4-locular; disc level to domed. Seeds irregular, angular, dull, brownish black, sometimes with a ragged translucent wing around the edge; hilum ventral; chaff angular, dark brown.

Distribution: Greenough River south to Hill River, in subcoastal areas (Fig. 9).

Ecology: a small tree or tall, few-stemmed 'Bull Mallee', locally abundant in mallee woodland thickets on calcareous sand of old beach dune systems, often partly indurated to form 'sheet limestone' in the soil. Known as 'Illyarrie' and widely cultivated for its conspicuous flowers and pleasant general appearance. 
Conservation status: not considered to be at risk.

Selected specimens (from 28 examined): Western Australia: Enneabba to Dongarra on highway, Blaxell W75/90, 7 Oct 1975 (NSW, PERTH); 14 km NNE of Dongarra, Brooker 8115, 24 May 1983 (CANB, NSW, PERTH); Bookara siding, Johnson W41, 11 Dec 1960 (NSW).

\section{Series Jucundae}

This series, although formerly misunderstood by us also, does not correspond with the group called series Jucundae by Chippendale (1988), the latter not a part of our extracodical system - see 'Terminology' above. The single species appears to have most in common with the groups here retained in our section Eudesmia, which is not necessarily fully supported by synapomorphies. However, it differs from all other series in its perianth development and structure, showing what we interpret as a parallel evolutionary condition to that in the members of Leprolaena (the E. miniataE. baileyana group) as indicated and discussed by Hill \& Johnson (1995, esp. pp. 188-193 and 481).

Bark smooth, with oil glands. Juvenile leaves petiolate, hispid with radiating hairs. Unit inflorescences axillary, often appearing compound, made up of three 3-flowered 'umbellasters', sometimes appearing simple and 9-flowered. Calyx fused to corolla, sometimes evident as 4 small teeth at apex of calyptra. Stamens continuous. Filaments white or cream.

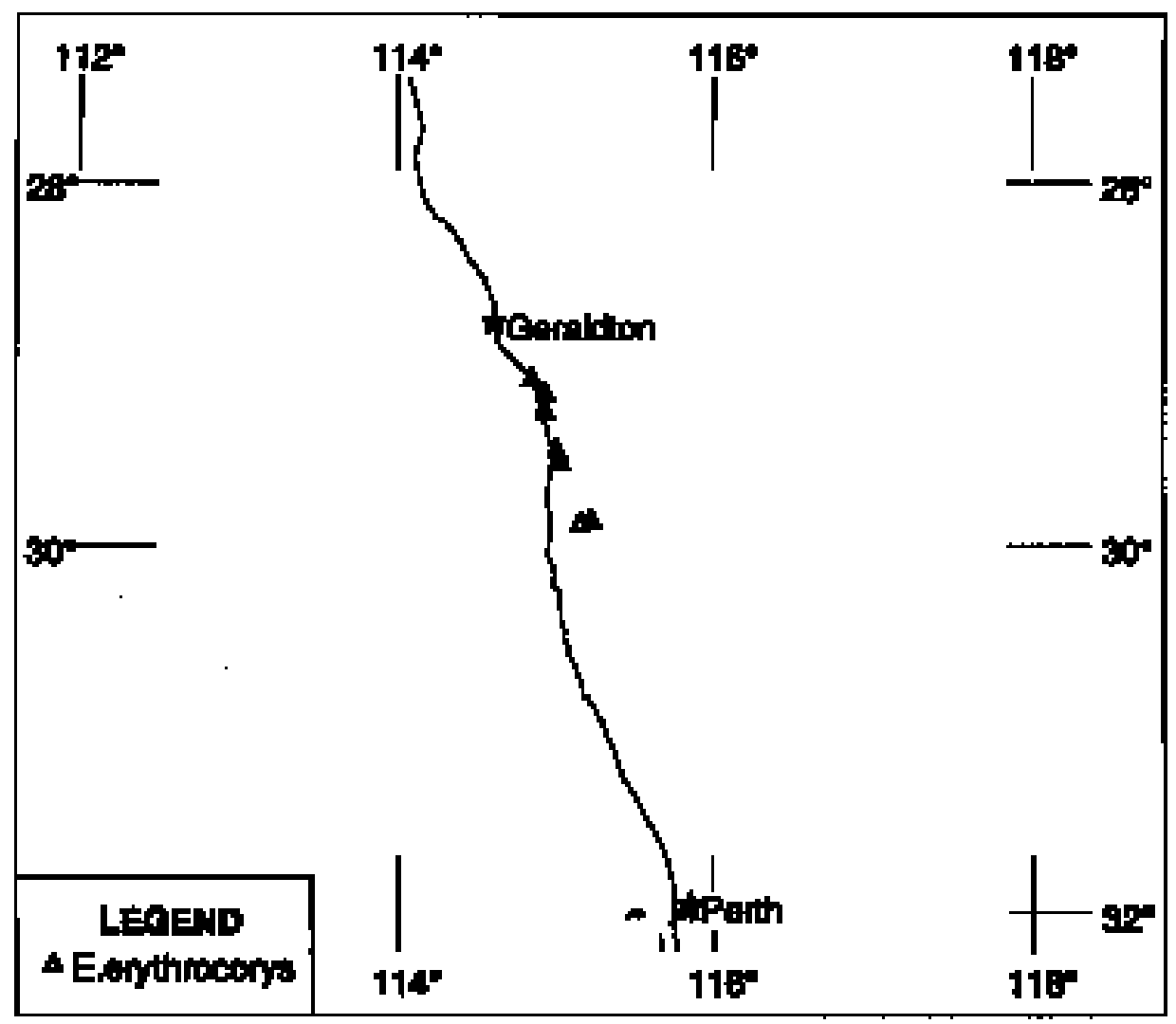

Fig. 9. Distribution of E. erythrocorys. 
In this and the following series, unit inflorescences often appear compound, but the limits of 'umbellasters' are not well-defined (as is true in a number of cases in section Eudesmia).

12. Eucalyptus jucunda C. Gardner, J. \& Proc. Roy. Soc. Western Australia 47: 60 (1964).

Type: Western Australia: near the Greenough River, C.A. Gardner 12066, 6 Jan 1959 (holo PERTH).

Mallee or small tree to $7 \mathrm{~m}$, usually less than $4 \mathrm{~m}$. Bark smooth, grey, grey-brown or pinkish brown, occasionally persistent on lower trunk, grey, shortly fibrous-flaky. Twigs and stems not pruinose. Juvenile leaves to $9 \mathrm{~cm}$ long, to $4.5 \mathrm{~cm}$ wide, opposite, petiolate, elliptical, becoming ovate, apically rounded, with 'stellate hairs'. Adult leaves 7-11 cm long, 7-20 mm wide, disjunct, narrow-lanceolate to lanceolate, acuminate, glabrous, dull, mid-green to grey-green, not pruinose; petioles $9-20 \mathrm{~mm}$ long; lateral veins at c. $30^{\circ}$ to midrib, moderately closely spaced; secondary reticulum incomplete; intramarginal vein irregular, 1-2 $\mathrm{mm}$ from leaf margin. Umbellasters compound (see above), axillary, 9-flowered; peduncles terete, 5-12 $\mathrm{mm}$ long; pedicels angular, 2-5 mm long. Mature buds ovoid to clavate, not quadrangular, not glaucous, 9-12 mm long, 6-8 mm diam.; calyx fused to corolla, persistent as 4 small teeth around top of calyptra on mature buds; calyptra hemispherical, c. $1 / 3$ as long as than hypanthium. Stamens all fertile; filaments regularly inflexed, white or cream; anthers oblong, versatile, dehiscing through parallel slits. Fruits 3-locular, subglobose to ovoid, constricted apically, 10-15 mm long, 10-13 mm diam.; disc 2-4 mm wide, strongly depressed; valves deeply enclosed. Seeds irregularly pyramidal, angular, dull, brownish black, with a ragged translucent wing around the edge; hilum ventral; chaff angular, dark brown.

Distribution: between Wannoo and Enneabba (Fig. 10).

Ecology: locally frequent on yellow sandplain in species-rich mixed shrublands. For apparent involvement in the ancestry of E. roycei, see under that species.

Conservation status: not considered to be at risk.

Selected specimens (from 27 examined): Western Australia: $67 \mathrm{~km} \mathrm{~S}$ of Wannoo, North Coastal Highway, N of Geraldton, Blaxell W 75/112 \& Brooker, 9 Oct 1975 (NSW, PERTH); between Morawa and Three Springs, Brooker 8731, 1 Nov 1984 (CANB, NSW); 90 miles [114.9 km] N of Murchison River Bridge, Burbidge 6514, 3 Sep 1959 (CANB, NSW); 7.9 miles [12.7 km] WSW of Tenindewa Siding, Chippendale 325, 17 Mar 1968 (CANB, NSW); $18 \mathrm{~km} \mathrm{~N}$ of Yuna on the Dairy Creek, Gascoyne Junction Road, Foreman 631, 10 Sep 1984 (MEL, AD, CANB, NSW, PERTH); Western Titanium leases, $8 \mathrm{~km} \mathrm{~S}$ of Eneabba, Hnatiuk 771336, 21 Sep 1977 (PERTH, NSW); $5 \mathrm{~km}$ along road to The Loop from junction with The Z Bend Road, Johnson 9400 \& Briggs, 12 Aug 1991 (NSW, PERTH CANB); Mullewa, Steedman 2, 30 Jan 1940 (NSW, AD, BRI, CANB, K, MEL, MO, PERTH); 413 Mile Peg on NW Coastal Highway, c. 30 miles [ 48.3 km] N of Murchison River Crossing, Tindale 2740, 21 Aug 1973 (NSW, CANB, K, MEL, PERTH).

\section{Series Royceanae}

Bark smooth, with oil glands. Juvenile leaves petiolate, hairy. Unit inflorescences axillary, often appearing compound, made up of three 3-flowered 'umbellasters', sometimes appearing simple and 9-flowered. Calyx irregularly fused to corolla, usually evident as 4 small teeth at apex of calyptra. Stamens continuous. Filaments white or cream.

13. Eucalyptus roycei S.G.M. Carr, D.J. Carr \& A.S. George, Proc. Roy. Soc. Victoria 83: 159, Figs. 2-8 (1970).

Type: Western Australia: near Hamelin Pool, 32.5 miles [52.3 km] along Loop Road, 64 miles [103.0 km] W of Overlander Road House, Great Northern Highway, E.M. 
Scrymgeour 284 E S.G.M. Carr, 2 Mar 1966 (holo PERTH; iso NSW). Cited as: 'E.M. Scrymgeour and S.G.M. Carr 284. PERTH.'

Mallee or small tree to $7 \mathrm{~m}$, usually less than $4 \mathrm{~m}$. Bark often persistent on lower trunk, grey, shortly fibrous-flaky, smooth above, grey, brownish cream or pinkish. Twigs and stems pruinose. Juvenile leaves to $8 \mathrm{~cm}$ long and $6 \mathrm{~cm}$ wide, opposite, petiolate, elliptical, becoming ovate to orbiculate, cordate, apically rounded, with 'stellate hairs'. Adult leaves $11-15 \mathrm{~cm}$ long, $1.4-2.8 \mathrm{~cm}$ wide, sub-opposite to disjunct, lanceolate to broad-lanceolate, acuminate, glabrous, dull, mid-green to grey-green, not pruinose; petioles 9-30 $\mathrm{mm}$ long; lateral veins at $30-40^{\circ}$ to midrib, moderately closely spaced; secondary reticulum incomplete; intramarginal vein irregular, c. $1 \mathrm{~mm}$ from leaf margin. Umbellasters compound (see above), axillary, 9-flowered; peduncles terete or angular, 9-20 mm long; pedicels angular, 2-5 $\mathrm{mm}$ long. Mature buds clavate, quadrangular, glaucous, $15-20 \mathrm{~mm}$ long, 7-11 mm diam.; calyx fused to corolla to a varying height, distinguishable at least as 4 small teeth around or near top of calyptra on mature buds; calyptra hemispherical, c. $1 / 3$ as long as than hypanthium. Stamens all fertile; filaments regularly inflexed, white or cream; anthers oblong, versatile, dehiscing through parallel slits. Fruits 3-locular, subglobose to oblong, quadrangular, constricted apically, 17-30 mm long, 15-25 mm diam.; disc 2-4 mm wide, strongly depressed; valves deeply enclosed. Seeds irregularly pyramidal, angular, dull, brownish black, with a ragged translucent wing around the edge; hilum ventral; chaff angular, dark brown.

The irregular degree of fusion between calyx and corolla points to an origin from hybridisation between E. gittinsii (subseries Tetragonosae) and E. jucunda (series Jucundae). These two species have not been observed growing in company at sites of E. roycei seen by us, but populations of E. roycei show a degree of instability in reproductive and vegetative characters that would indicate hybridisation not too far in the past, despite the fairly strong differences in appearance between the taxa.

Distribution: a restricted area south-east of Shark Bay and north-west of Wannoo (Fig. 10).

Ecology: an uncommon species in species-rich mixed shrublands on somewhat calcareous orange or red aeolian sand deposits.

Conservation status: not considered to be at risk.

Selected specimens (from 11 examined): Western Australia: between Hamelin and Tamala, Beard 6793, 10 Oct 1973 (PERTH, NSW); 23 km from Coburn to Hamelin, Shark Bay, Blaxell W 75/102, 8 Oct 1975 (NSW, K, PERTH); 17 km NNW of Coburn Station, Brooker 5013 \& Blaxell, 8 Oct 1975 (CANB, NSW); 9 km W of Coburn [homestead], Brooker 8132, 27 May 1983 (CANB, NSW); Tamala road $2.7 \mathrm{~km} \mathrm{~S} \mathrm{~W} \mathrm{of} \mathrm{Denham} \mathrm{road,} \mathrm{Johnson} 9376$ \& Briggs, 10 Aug 1991(NSW, PERTH); Tamala [Homestead], Sharks Bay, Kruiskamp (NSW); 35.5 miles [57.1 km] along Loop Road from Coastal Highway, Scrymgeour 297, 2 Mar 1966 (PERTH, NSW); 32.9 miles [53.0 km] along Loop Road, 64 miles [103.0 km] W of Overlander Road House, Great Northern Highway, Scrymgeour 293, 2 Mar 1966 (PERTH, NSW).

\section{Series Ebbanoenses}

This has the same content as the series of the same name described by Chippendale (1988), although no subspecies were recognised by him. We repeat that the series as recognised by Chippendale are not part of our extracodical series.

Bark smooth, with oil glands. Juvenile leaves petiolate, disjunct. Conflorescences axillary, simple, 3-flowered. Calyx fused to corolla, sometimes evident as 4 suture lines on calyptra. Stamens in 4 bundles. Filaments white or cream. 
A single species is included in this series.

14. Eucalyptus ebbanoensis Maiden, Crit. Revis. Eucalyptus 5: 169, plate 189, Figs. 6, 7 (1921).

Type: Western Australia: Ebbano, east from Mingenew, A. Morrison s.n., 28 Sep 1904 (holo NSW 341209).

Mallee to $6 \mathrm{~m}$, usually less than $4 \mathrm{~m}$. Bark smooth, grey, grey-brown or bronze, sometimes with a short persistent stocking on the lower trunk of larger individuals. Juvenile leaves to $10 \mathrm{~cm}$ long and $4 \mathrm{~cm}$ wide, disjunct, petiolate, narrowly elliptical, apically rounded, with 'stellate hairs'. Adult leaves 5-12 cm long, $0.7-2.2 \mathrm{~cm}$ wide, disjunct, narrow-lanceolate to lanceolate, acuminate, glabrous; petioles 8-15 mm long; lateral veins at c. $30^{\circ}$ to midrib, moderately closely spaced; secondary reticulum incomplete; intramarginal vein irregular, c. $1 \mathrm{~mm}$ or less from leaf margin. Umbellasters simple, axillary, 3-flowered; peduncles terete or angular, 5-13 mm long; pedicels terete, 1-6 mm long. Mature buds ovoid to pyriform, 6-8 mm long, $4-5 \mathrm{~mm}$ diam.; calyx free, often difficult to discern but persistent as 4 or often only 2 small teeth around top of hypanthium on mature fruits; calyptra hemispherical, $1 / 2$ to about as long as hypanthium, usually with 4 calycine suture lines evident. Stamens all fertile, in 4 fascicles; filaments regularly inflexed; anthers oblong, versatile, dehiscing through parallel slits. Fruits 3-locular, globular-truncate to cup-shaped, 7-11 mm long, 8-12 mm

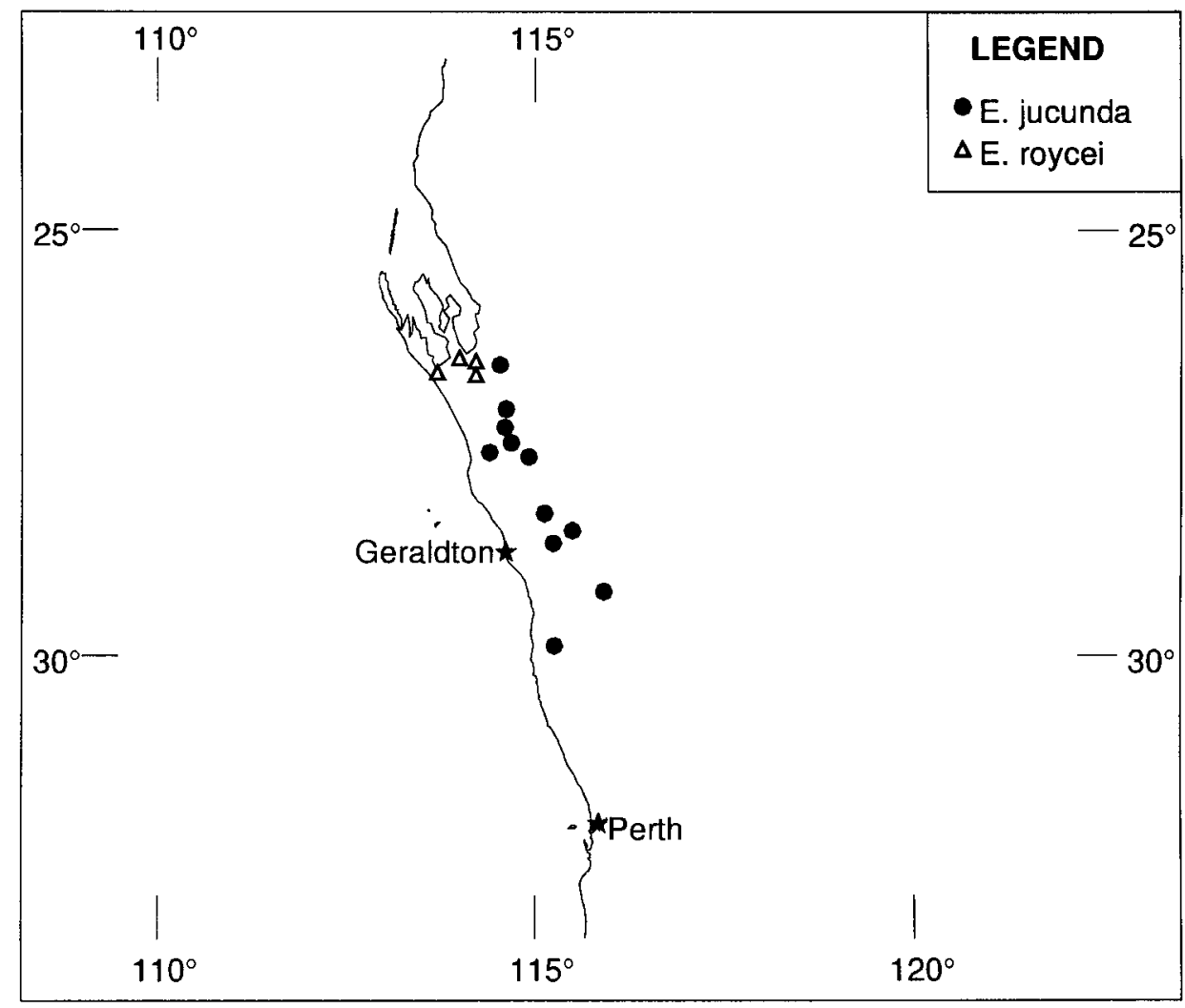

Fig. 10. Distribution of E. roycei, E. jucunda. 
diam.; disc 2-3 mm wide, level to slightly raised; valves enclosed. Seeds ovoid or cuboid, dull, brownish black, not winged; hilum ventral; chaff angular, dark brown.

Three geographic subspecies are recognised, as follows.

1 Adult leaves dull

2 Twigs buds and fruits not glaucous

14A. subsp. ebbanoensis

2 Twigs buds and fruits glaucous

14C. subsp. glauciramula

1 Adult leaves glossy

14B. subsp. photina

14A. Eucalyptus ebbanoensis Maiden subsp. ebbanoensis

Distribution: Canna-Mingenew to Wongan Hills, and sporadically east to near Koolyanobbing (Fig. 11). Although geographically closer to occurrences of subsp. glauciramula, the collection from near Koolyanobbing clearly represents the type subspecies.

Ecology: widespread but sporadic in mallee shrublands on yellow or red sand over laterite.

Conservation status: not considered to be at risk.

Selected specimens (from 17 examined): Western Australia: 9.8 miles [15.8 km] W of Three Springs, Allan 650, 18 July 1971 (PERTH, NSW); Koolanooka Range near Morawa, Beard 6704, 27 Sep 1973 (PERTH, NSW); 11.5 km NW of Three Springs along Midlands Road, Briggs 7749 \& Johnson, 1 Oct 1984 (NSW, CANB, PERTH); $20.2 \mathrm{~km}$ NE or Arrino towards Morawa, Brooker 8732, 1 Nov 1984 (CANB, NSW); S of Pintharuka rd, 9.6 km from Mingenew-Morawa rd via Yandanooka rd, Brooker 9753 a, 9 Sep 1987 (NSW, AD, BRI, CANB, DNA, K, MEL, PERTH, US); 18 miles [29.0 km] E of Mingenew, Chippendale 41, 19 Oct 1966 (CANB, NSW); 3 miles SE of Canna turn-off, Chippendale 53, 20 Oct 1966 (CANB, NSW); $25 \mathrm{~km}$ from Piawaning along road to Wongan Hills town, $1 \mathrm{~km} \mathrm{~S}$ of road, Crisp 5483, 26 Jan 1979 (CANB, NSW, PERTH); ca. $7.5 \mathrm{~km} \mathrm{NE}$ of Bungalbin Hill, Helena Aurora Range, ca. 50 km NNE of Koolyanobbing, Lepschi 2000, 25 Sep 1995 (PERTH, BRI, CANB, NSW).

14B. Eucalyptus ebbanoensis Maiden subsp. photina Brooker E Hopper, Nuytsia 9: 2 (1993).

Type: Western Australia: Nanson Road, 28 34'S, 114 43'E, M.I.H. Brooker 9195 E S.D. Hopper (holo PERTH; iso CANB, MEL, NSW).

Distinguished from the other two subspecies of E. ebbanoensis by the glossy leaves that are consistent across the known populations.

Distribution: north and east of Geraldton, primarily around the Morseby Range, and south to Mt Horner (Fig. 11).

Ecology: localised and sporadic, on lateritic breakaways.

Conservation status: not considered to be at risk.

Selected specimens (from 11 examined): Western Australia: 8 miles [12.9 km] W of Tenindewa, Beard 6913, 24 Oct 1973 (PERTH, NSW); Burma Road Nature Reserve, E side $200 \mathrm{~m}$ from fence, Brooker 7944, 26 Jan 1983 (CANB, NSW); Breakaway SSE of Mount Horner, N of Pincher's road, Brooker 8817, 4 Feb 1985 (CANB, NSW); Nanson road, Brooker 9195, 12 Mar 1986 (CANB, NSW); 3.7 miles [6.0 km] E of Eradu Siding, Chippendale, 17 Mar 1968 (CANB); Mount Michael, Hill 2572 \& Johnson, 23 Nov 1986 (NSW, CANB, MEL, PERTH).

14C. Eucalyptus ebbanoensis Maiden subsp. glauciramula L.A.S. Johnson E K.D. Hill, subsp. nov.

A subspecie typica ramulis alabastris fructibus pruinosis differt. 
Type: Western Australia: $10.6 \mathrm{~km}$ south of Diemals-Menzies road on Bullfinch road, K.D. Hill 2612 \& L.A.S. Johnson, 25 Nov 1986 (holo NSW; iso PERTH).

Distinguished from the other subspecies of E. ebbanoensis by the glaucous branchlets, a character no less consistent or demarcated geographically or morphologically than the leaf glossiness of subsp. photina.

Distribution: from south of Diemals east to the western edges of the Great Victoria Desert, from Pinjin to Cardunia (Fig. 11).

Ecology: widely scattered on red sand or loam, often lateritic, with Triodia.

Conservation status: not considered to be at risk.

The epithet is from the Latin glaucus, blue-green, and ramula, a branchlet, from the glaucous branchlets.

Selected specimens (from 15 examined): Western Australia: near Sand Queen Mine, 61.6 miles [99.2 km] N of Kalgoorlie, Baker 86, 17 Nov 1970 (CANB, NSW); between Davyhurst \& Goongarrie, Beard 6263, 10 Sep 1970 (KPBG, NSW); c. 3 km N of Karonie Siding on track to Cardunia Rocks, E of Kalgoorlie, Blaxell 1657, 20 June 1978 (NSW, PERTH); $6.3 \mathrm{~km} \mathrm{~W}$ of Broad Arrow on Ora Banda track, Brooker 8061, 8 Apr 1983 (CANB, NSW); 43 km from Pinjin at turn-off to Lake Minigwal, Brooker 8593, 15 May 1984 (CANB, NSW); 1.2 km SW of Carr Boyd Mine, Brooker 9614, 6 May 1987 (CANB, NSW); Comet Vale, Jutson 115, Dec 1916 (NSW); 60 miles [96.6 km] N of Kalgoorlie, Eremean Province, Speck 911, (CANB, NSW).

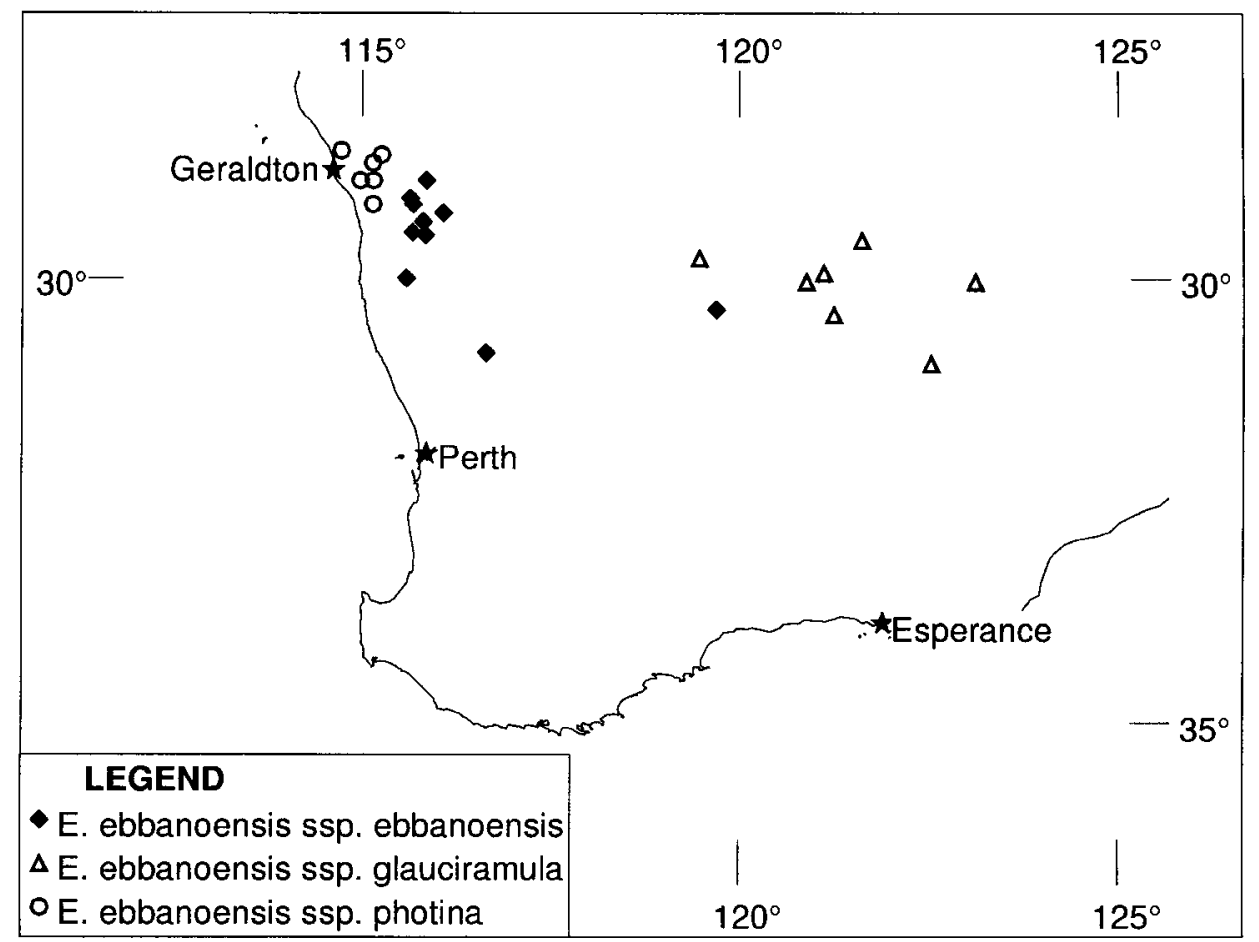

Fig. 11. Distribution of E. ebbanoensis subspp. ebbanoensis, photina, and glauciramula. 


\section{Section Fibraria}

Treated as series Tetrodontae Chippendale (1988). Chippendale's name is not part of our extracodical system.

Bark wholly persistent, long-fibrous, included oil glands present. Hairs not present on juvenile growth; juvenile leaves disjunct, petiolate. Adult leaves disjunct. Conflorescence simple, axillary, 7-flowered. Calyx reduced, persistent as 4 prominent rounded teeth at top of hypanthium. Stamens in 4 bundles. Filaments cream to yellow.

The sectional name refers to the distinctive long-fibrous bark, which is unique to this taxon within Eudesmia, and can be regarded as autapomorphic.

15. Eucalyptus tetrodonta F. Muell., J. Linn. Soc., Bot. 3: 97 (1859).

Type: Cited as: 'Hab. In plagis elevatis nemorosis minus fertilibus terrae Arnheim's Land passim. (Ad Portum Essington, Armstrong; et in ora boreali, A. Cunningham, in hb. Hook.) Anth. Aug., Sept.'

Maiden (Crit. Revis. Eucalyptus 5: 152) stated that the Type was a Mueller collection from the entrance to the Victoria River, and he was followed by Blake (1953, plate 9). This can be regarded as a formal lectotypification, although there is no support for this typification in Mueller's citation. However, much of Mueller's citation was added by Black at Kew during editing of the paper, and the specimens cited were not available to Mueller when he was drawing up the protologue.

Tree to $25 \mathrm{~m}$. Bark persistent throughout, thin, long-fibrous with stiff, brittle fibres, grey, dark red-brown on fresh breaks. Juvenile leaves to $35 \mathrm{~cm}$ long and $10 \mathrm{~cm}$ wide, dull, green to bluish green, disjunct, petiolate, broad-lanceolate to ovate, acuminate strongly falcate, lacking 'stellate hairs'. Adult leaves $10-20 \mathrm{~cm}$ long, $1.5-3 \mathrm{~cm}$ wide, dull, green to bluish green, disjunct, lanceolate, acuminate, glabrous; petioles $1020 \mathrm{~mm}$ long; lateral veins at c. $30^{\circ}$ to midrib, moderately closely spaced; secondary reticulum incomplete; intramarginal vein irregular, c. $1 \mathrm{~mm}$ or less from leaf margin. Umbellasters simple, axillary, 3-flowered; peduncles terete or angular, 1-5 $\mathrm{mm}$ long; pedicels terete, 5-13 mm long. Mature buds ovoid to pyriform, 10-25 mm long, 6-11 mm diam.; calyx free, distinct and persistent as 4 large rounded teeth at top of hypanthium; calyptra hemispherical, $1 / 2$ as long as hypanthium. Stamens all fertile, in 4 fascicles; filaments regularly inflexed; anthers oblong, versatile, dehiscing through parallel slits. Fruits 3-locular, cup-shaped to campanulate, 13-22 mm long, 10-14 mm diam.; calyptra scar distinct and raised, disc $2-3 \mathrm{~mm}$ wide, level to slightly raised; valves enclosed. Seeds ovoid or cuboid, dull, greyish black, not winged; hilum ventral; chaff angular, dark brown.

Distribution: northern Australia, widespread and abundant in the wetter monsoon tropics of Western Australia, Northern Territory and Queensland (Fig. 12).

Ecology: a locally abundant species dominating savanna forests on residual sand over laterite and generally sandy soils, frequently associated with E. miniata and an understorey often dominated by Sorghum or similar annual grasses.

Conservation status: not considered to be at risk.

Selected specimens (from 106 examined): Northern Territory: Narbarlek, Hinz 522, 11 May 1989 (DNA, AD, BRI, CANB, DNA, NSW); SE corner of Arafura Swamp, Dunlop $8715 \mathcal{E}$ White, 3 July 1990 (DNA, CANB, DNA, NSW); N of Mataranka towards Katherine, along the Stuart Highway, Munir 6233, 14 June 1988 (AD, NSW); 17 miles [28 km] W of Wollogorang at Red Bank mines Airstrip, Carolin 9233, 13 May 1974 (NSW, NSW); $3.1 \mathrm{~km}$ E of Dhalinbuy turn-off, Hill $3951 \mathcal{E}$ Stanberg, 27 Aug 1991 (NSW, CANB, DNA); 9.2 m. [km] S [of] Danger Point, Cobourg Peninsula, Chippendale NT 8229, 20 July 1961 (DNA, NSW); Pickertaramoor, Melville Island, Brooker 3189, 23 June 1971 (CANB, NSW); Little Lagoon, Groote Eylandt, Gulf of Carpentaria, Specht 444, 30 May 
1948 (CANB, NSW); 15 km N [of] Nathan River homestead, Wightman 1865 E Leach, 8 May 1985 (DNA, CANB, NSW, NT).

Queensland: 10 km S of Normanton, Beadle 215, 8 Sep 1972 (NSW); 9 km W of Gilbert River on Croydon road, Benson 842, 19 June 1974 (NSW); Kennedy road, 36 miles [57.6 km] beyond Laura, Gittins 971, July 1965 (NSW 304243); 5 miles [8 km] from Telegraph Line on Iron Range Rd, Nth Qld, Gittins 1784, July 1968 (NSW); E of Heathland, Johnson 7763, 17 Aug 1974 (NSW); Killarney Road, $12 \mathrm{~km} \mathrm{~N}$ of Kimba - Laura road, Dalliston CC 54, 28 June 1988 (BRI, CANB, NSW); 5 miles [8 km] S Cooktown on road to Cairns, Briggs 2015, 4 Aug 1968 (NSW).

Western Australia: 20 miles [33 km] NW of Beverley Springs station, Aplin 5678, 11 July 1973 (PERTH, NSW); old CRA camp on King Edward River, $1 \mathrm{~km} \mathrm{~S} \mathrm{of} \mathrm{ford} \mathrm{crossing} \mathrm{of} \mathrm{disused} \mathrm{Mitchell}$ River station track, N Kimberley, Edinger 351, 10 June 1987 (PERTH, NSW); Kalumburu district, ca 200 km NW of Wyndham, Johnson 2035a, 23 Aug 1967 (NSW); 24 miles [39 km] SE of Kimberley Research Station, Perry 2939, 9 July 1952 (CANB, NSW); 5 miles [8 km] SE of Mt Russ on tributary of Drysdale River, Kimberley, Banks 1462, 6 Oct 1968 (NSW).

\section{Section Apicaria}

Bark persistent, long-fibrous with distinctive included flakes, usually shedding on outer to larger branches, oil glands present in bark. Radiating hairs present on juvenile growth; juvenile leaves petiolate. Conflorescence simple, axillary, 3-7-11-manyflowered. Calyx reduced, persistent as teeth at top of hypanthium. Stamens in 4 bundles. Filaments white or cream or orange.

The fibrous bark with included mica-like flakes is similar to that occurring in Corymbia jacobsiana and Eucalyptus microcorys. This is clearly a parallel development in C. jacobsiana, but the situation is less clear in the case of E. microcorys. One possible explanation is that the latter also represents a parallel development. If so, the bark condition can be viewed as an apomorphy uniting this section.

The sectional name refers to the reduced calyx persisting as teeth at top of hypanthium.

Three series are distinguished.

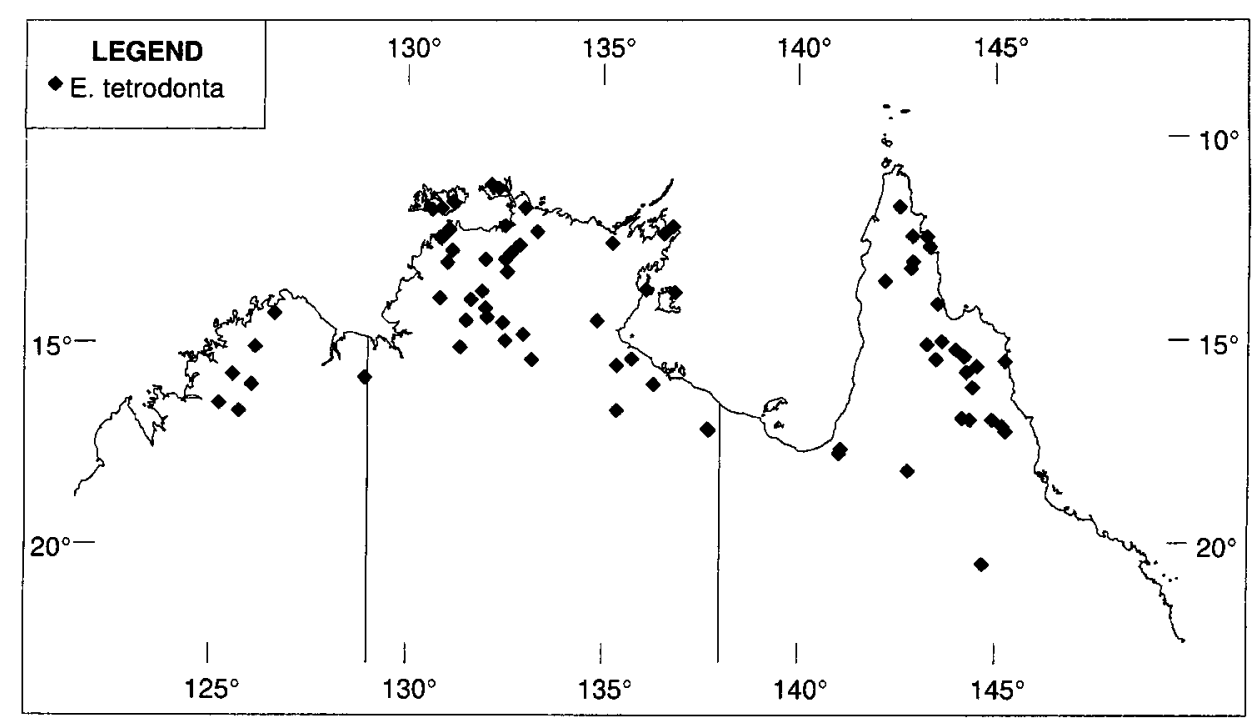

Fig. 12. Distribution of E. tetrodonta. 


\section{Series Similes}

Included in Series Scutelliformes Maiden together with E. baileyana by Chippendale (1988). This name is not part of our extracodical system.

Small trees, often with several trunks. Bark persistent throughout, soft, pale yellowbrown. Juvenile and adult leaves disjunct (secondarily opposite in E. ceracea). Umbellasters 3-flowered. Flowers white. Style long, bent.

16. Eucalyptus lirata W. Fitzg. ex Maiden, Crit. Revis. Eucalyptus 5: 111 (1921).

Type: Western Australia: summit of Bold Bluff, Kimberleys, W.V. Fitzgerald 843 (holo NSW).

Tree to $12 \mathrm{~m}$, often with several trunks. Bark persistent throughout, fibrous with soft, flexible fibres and included mica-like flakes, yellow to orange-brown. Juvenile leaves to $12 \mathrm{~cm}$ long and $3.5 \mathrm{~cm}$ wide, dull, green to bluish green, disjunct, petiolate, lanceolate, with 'stellate hairs'. Adult leaves 7-12 cm long, 1.5-2.5 cm wide, dull, green to bluish green, disjunct, lanceolate, acute, glabrous; petioles 10-20 mm long; lateral veins at c. $30^{\circ}$ to midrib, moderately closely spaced; secondary reticulum incomplete; intramarginal vein irregular, c. $1 \mathrm{~mm}$ or less from leaf margin. Umbellasters simple, axillary, 3-flowered; peduncles terete or angular, 20-30 mm long; pedicels terete, 3-6 mm long. Mature buds fusiform with a distinct median constriction, 8-12 mm long, 4-6 mm diam.; calyx indistinct, \pm fused to corolla, evident as 4 small teeth at apex of calyptra; calyptra conical, $1 / 2-2 / 3$ as long as hypanthium. Stamens all fertile, in a continuous ring; filaments regularly inflexed; anthers oblong, versatile, dehiscing through parallel slits. Fruits 3-4-locular, cup-shaped to globular or weakly urceolate, 10-12 mm long, 8-10 mm diam.; calyptra scar distinct and raised, disc 2-3 mm wide, level to slightly raised; valves enclosed. Seeds elliptical, dull, greyish black, not winged; hilum ventral; chaff angular, dark brown.

Distribution: northern W.A., restricted to the central Kimberley region (Fig. 13).

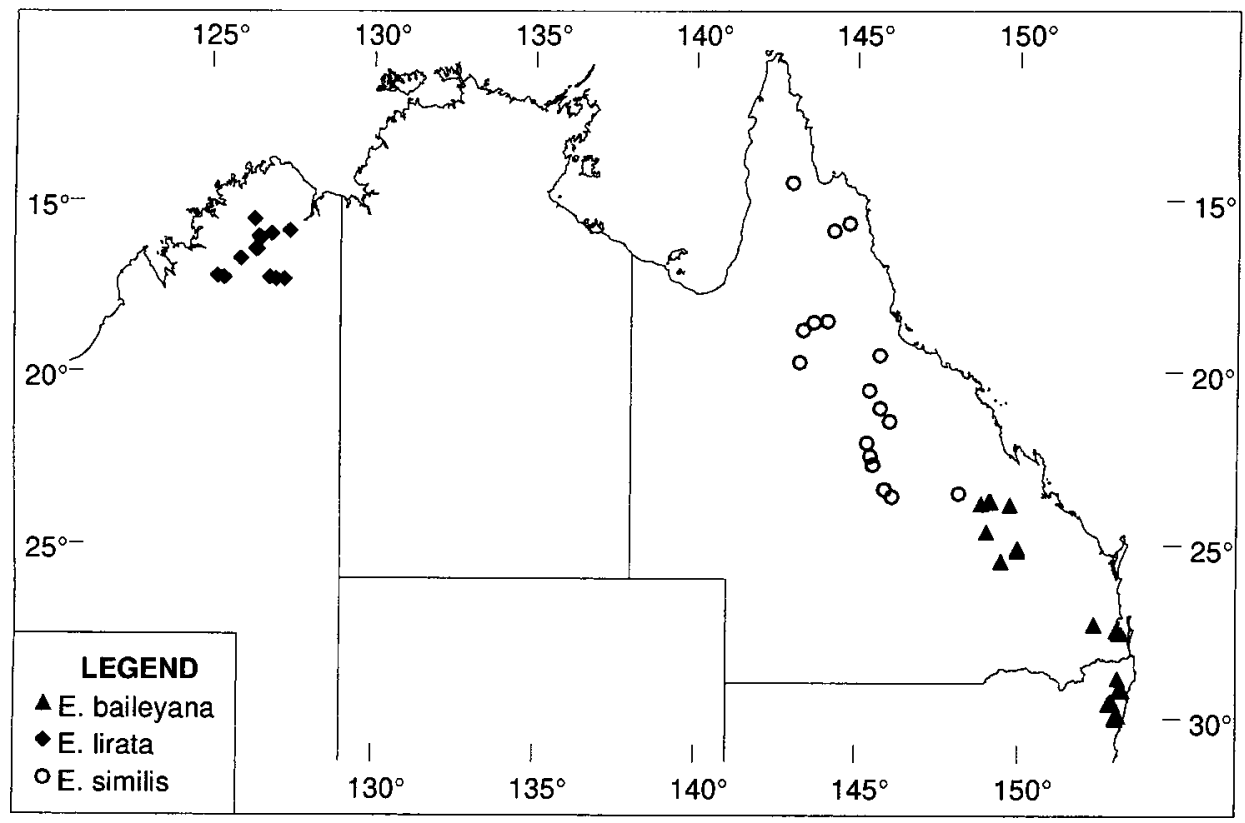

Fig. 13. Distribution of E. baileyana, E. similis and E. lirata. 
Ecology: a locally abundant species dominating low open savanna woodlands on shallow to skeletal sand over laterite or sandstone, with an understorey often dominated by Triodia.

Conservation status: not considered to be at risk.

Selected specimens (from 23 examined): Western Australia: 2.5 miles [4 km] W of Gibb River Station, Aplin 5543, 29 June 1973 (PERTH, NSW); 79 km SW of Pentecost River crossing on Gibb River road, Hill 942, Johnson E Benson, 23 July 1984 (NSW, DNA, FRI, PERTH); Teronis Gorge, Hill 3484, Johnson \& Stanberg, 26 Nov 1988 (NSW, CANB, PERTH); 112.4 miles [180 km] by road W of King River Crossing towards the Gibb River - Kalumburu road, Brooker 4254, 1 Nov 1973 (NSW 314697, NSW); Kimberley district - 46 km from Gibb River homestead along Kulumburu road towards Drysdale River, Telford 6256 \& Butler, 29 July 1977 (CANB, NSW, PERTH).

17. Eucalyptus similis Maiden, J. E Proc. Roy. Soc. New South Wales 47: 90 (1913).

Type: Queensland: from desert country W of Emerald, G.H. Carr s.n., Mar 1908 (holo NSW; iso K).

Tree to $8 \mathrm{~m}$, often with several trunks. Bark persistent throughout, fibrous with soft, flexible fibres and included mica-like flakes, yellow to orange-brown. Juvenile leaves to $9 \mathrm{~cm}$ long and $3.5 \mathrm{~cm}$ wide, dull, green to bluish green, disjunct, petiolate, broadlanceolate, with 'stellate hairs'. Adult leaves 8-14 cm long, 1-2 cm wide, dull, green to bluish green, disjunct, lanceolate to broad-lanceolate, acute, glabrous; petioles $10-20 \mathrm{~mm}$ long; lateral veins at c. $30^{\circ}$ to midrib, moderately closely spaced; secondary reticulum incomplete; intramarginal vein irregular, c. $1 \mathrm{~mm}$ or less from leaf margin. Umbellasters simple, axillary, 3-flowered; peduncles terete or angular, 7-10 mm long; pedicels terete, $2-5 \mathrm{~mm}$ long. Mature buds cylindrical to fusiform, with a distinct median constriction, 8-14 mm long, 4-6 mm diam.; calyx indistinct, \pm fused to corolla, evident as 4 small teeth at apex of calyptra; calyptra hemispherical to broadly conical, $1 / 2$ as long as hypanthium. Stamens all fertile, in a continuous ring; filaments regularly inflexed; anthers oblong, versatile, dehiscing through parallel slits. Fruits 3-locular, truncate-ovoid to cylindrical or weakly urceolate, 10-13 mm long, 7-9 mm diam.; calyptra scar distinct and raised, disc 2-3 mm wide, level to slightly raised; valves enclosed. Seeds elliptical, dull, greyish black, not winged; hilum ventral; chaff angular, dark brown.

Distribution: northern central Queensland, from the Newcastle Range to east of Barcaldine (Fig. 13).

Ecology: a locally abundant species dominating low open savanna woodland, usually on sand over laterite or sandstone, with an understorey often dominated by Triodia.

Conservation status: not considered to be at risk.

Selected specimens (from 35 examined): Queensland: $4 \mathrm{~km} \mathrm{~W}$ of Amelia Creek crossing, on Longton - Oxenhope road, Neldner 3159 \& Thompson, 11 May 1991 (BRI, NSW); 6 miles [9.6 km] NW of Middle Park station, Pryor 4092 Johnson \& Lazarides, 17 Sep 1953 (NSW); c. 20 km W of Einasleigh on Einasleigh to Forsayth road, Clarkson 2582 \& Byrnes, 12 Aug 1979 (BRI, NSW); N of Laura River near Early Man site, Byrnes 3350, 16 May 1975 (BRI, NSW); 14 km E of Strathburn Homestead (approximately $70 \mathrm{~km}$ NNE of Musgrave), Milne 12 \& DeLai, 17 July 1994 (BRI, MBA, NSW, CANB); $57.9 \mathrm{~km}$ E of Barcaldine towards Jericho, Brooker 7863, 7 Dec 1982 (CANB, NSW); $47.3 \mathrm{~km}$ from Aramac on Eastmere Road, Hill 1176 \& Johnson, 20 Aug 1984 (NSW); between Pentland \& Warrigal, Hyland 6129, 18 May 1972 (QRS, NSW); 10 miles [16 km] E of Yarrowmere station, S Kennedy District, Adams 982, 24 May 1964 (BRI, NSW).

\section{Series Baileyanae}

Included in Series Scutelliformes Maiden together with E. similis and E. lirata by Chippendale (1988). This name is not part of our extracodical system. 
Tall trees. Bark persistent throughout, hard, dark red-brown. Umbellasters 3-flowered. Flowers white. Style short, straight.

18. Eucalyptus baileyana F. Muell., Fragm. 11: 37 (1878).

Type: Queensland: near Moreton Bay, F.M. Bailey s.n., 1869 (holo MEL; iso NSW, BRI, K). Cited as: 'Ad sinum marinum Moreton-Bay rara; Bailey.'

Tree to $25 \mathrm{~m}$, sometimes to $40 \mathrm{~m}$. Bark persistent throughout, fibrous with soft, flexible fibres and included mica-like flakes, red-brown to deep brown. weathering grey. Juvenile leaves to $13 \mathrm{~cm}$ long, to $7 \mathrm{~cm}$ wide, dull, green to bluish green, disjunct, petiolate, broad-lanceolate to ovate, cordate, with 'stellate hairs'. Adult leaves $8-15 \mathrm{~cm}$ long, 1-2.5 cm wide, glossy, green, disjunct, narrow-lanceolate to lanceolate, acute, glabrous; petioles $10-20 \mathrm{~mm}$ long; lateral veins at c. $30^{\circ}$ to midrib, moderately closely spaced; secondary reticulum incomplete; intramarginal vein irregular, c. $1 \mathrm{~mm}$ or less from leaf margin. Umbellasters simple, axillary, 3-flowered; peduncles terete or angular, 15-25 mm long; pedicels terete, 2-11 mm long. Mature buds clavate, $6-8 \mathrm{~mm}$ long, 3-4 mm diam.; calyx indistinct, \pm fused to corolla, evident as 4 small teeth at apex of calyptra; calyptra hemispherical, apiculate or slightly beaked, $1 / 2$ as long as hypanthium. Stamens all fertile, in 4 discrete bundles; filaments regularly inflexed; anthers oblong, versatile, dehiscing through parallel slits. Fruits 3-locular, ovoid to globular or weakly urceolate, 8-14 mm long, 8-16 mm diam.; calyptra scar distinct and raised, disc 2-3 mm wide, level to slightly raised; valves enclosed. Seeds elliptical, dull, greyish black, not winged; hilum ventral; chaff angular, dark brown.

Distribution: Queensland and northern N.S.W., from the Blackdown Tableland to near Coffs Harbour, somewhat sporadic (Fig. 13).

Ecology: an abundant but quite localised species, usually in tall mixed dry sclerophyll forests on infertile sandy soils over sandstone, with a rich mixed shrub understorey.

Conservation status: not considered to be at risk.

Selected specimens (from 63 examined): New South Wales: North Coast: $41.7 \mathrm{~km}$ from Coffs Harbour past Glenreagh, Brooker 6100, 28 Jan 1979 (CANB, NSW); Tabulam — Copmanhurst road, c. $6.4 \mathrm{~km} \mathrm{~S}$ of Coaldale, Johnson 341, 24 Apr 1969 (NSW); Rocky Creek, c. 2 miles (3.2 km) N of Coaldale-rd [19 miles (30.6 km) NNW of Grafton], Coveny 4983, 23 Aug 1973 (NSW); Fortis Creek, $24 \mathrm{~km}$ N of Grafton on the road to Coaldale, Foreman 912, 23 Aug 1985 (MEL, CANB, NE, NSW, WELTU).

Queensland: Blackdown Tableland, c. $32 \mathrm{~km}$ SE of Blackwater (campsite on Mimosa Creek), alt. 600-900 m. c. 6.8 km NNE of campsite, Henderson 01183, Durrington \& Sharpe, 14 Sep 1971 (BRI, NSW); hillcrest on track to Robinson Gorge, NW of Taroom, Brooker B4845, 24 Apr 1975 (CANB, NSW); near Stoney Creek, Blackdown Tableland National Park, Blaxell 89/222 Johnson \& D'Aubert, 8 Aug 1989 (NSW); Brisbane, Toohey Park, Tarragindi, Telford s.n., 20 May 1969 (CANB, NSW); SW of Mt Gravatt (6 miles [9.6 km] S of Brisbane), Johnson s.n., 3 June 1951 (NSW).

\section{Series Miniatae}

Treated as Series Miniatae Blakely by Chippendale (1988). This name is not part of our extracodical system.

Small to tall trees. Bark shedding on branches. Umbellasters 7- or more-flowered. Flowers orange. Style long, bent.

Although this is a closely coherent series, two species groups can be recognised. These are treated below as subseries. The brightly orange-coloured flowers are synapomorphic. 


\section{Subseries Miniatosae}

Umbellasters 7-flowered.

19. Eucalyptus miniata A. Cunn. ex Schauer in Walp., Rep. Bot. Syst. 2: 925 (1843).

Type: Western Australia: Hunters R., York Sound, A. Cunningham 241, 10 Sep 1820 (holo: K; iso BM). Cited as: 'A. Cunn. Herb. no. 241/1820!'

= E. aurantiaca F. Muell., J. Linn. Soc., Bot. 3: 91 (1859).

Type: Shores of Gulf of Carpentaria; F. Mueller (holo MEL). Cited as: 'Hab. In planitiebus arenosis sicuti in plagis elevatioribus petraeis circum sinum Carpentaria, ubi vegetationis ornamentum. Anth. Mai. - Aug.'

Tree to $30 \mathrm{~m}$. Bark persistent on trunk, fibrous with soft, flexible fibres and included mica-like flakes, orange-brown to red-brown, weathering dark brown to black; smooth above, white to pale grey. Juvenile leaves to $12 \mathrm{~cm}$ long and $5 \mathrm{~cm}$ wide, dull, green to bluish green, disjunct, petiolate, ovate to elliptical, with 'stellate hairs'. Adult leaves 8-16 cm long, 1-3.5 cm wide, dull, green to bluish green, disjunct, narrow- to broadlanceolate, acute, glabrous; petioles $12-20 \mathrm{~mm}$ long; lateral veins at c. $30^{\circ}$ to midrib, moderately closely spaced; secondary reticulum incomplete; intramarginal vein irregular, c. $1 \mathrm{~mm}$ or less from leaf margin. Umbellasters simple, axillary, 7-flowered; peduncles terete or angular, 10-35 mm long; pedicels absent or terete, $0-5 \mathrm{~mm}$ long. Mature buds ovoid, \pm strongly ribbed, 18-25 mm long, 10-12 mm diam.; calyx indistinct, \pm fused to corolla, evident as 4 small teeth at apex of calyptra; calyptra hemispherical to conical, $1 / 2-2 / 3$ as long as hypanthium. Stamens all fertile, in a continuous ring; filaments regularly inflexed; anthers oblong, versatile, dehiscing through parallel slits. Fruits 3-locular, ovoid to urceolate, strongly to weakly ribbed, 30-50 mm long, 18-40 mm diam.; calyptra scar distinct and raised, disc 2-3 mm wide, level to slightly raised; valves enclosed. Seeds elliptical, dull, greyish black, not winged; hilum ventral; chaff angular, dark brown.

Distribution: northern Australia, widespread and abundant in wetter parts of the monsoon tropics of northern Western Australia, Northern Territory and Queensland (Fig. 14).

Ecology: a locally abundant species dominating savanna forests on residual sand over laterite and generally sandy soils, with an understorey often dominated by Sorghum or similar annual grasses. E. miniata is a variable species occurring across a wide range, and close study of regional variation is likely to define additional taxa at specific or subspecific rank. For example, Queensland occurrences display a generally lighter bark, and occurrences on slopes of the Arnhem Land escarpment display more complex ornamentation on buds and fruits

Although hybrids are uncommon in the subgenus, one specimen of a putative hybrid between E. miniata and E. phoenicea is known (cited below).

Conservation status: not considered to be at risk.

Selected specimens (from 114 examined): Northern Territory: Nitmiluk National Park, Wightman 5841 \& Sirikolo, 4 Aug 1992 (DNA, NSW); Pine Creek Road 62 km from Park Kakadu National Park, Boland 2169 \& Wardman, 19 Nov 1984 (CANB, NSW); 6 miles [9.6 km] N of Wollogorang station, Perry 1183, 2 June 1948 (CANB, NSW); 126.6 km E of Manangoora turn-off on Borroloola Burketown road, Hill 4134 \& Stanberg, 26 Sep 1991 (NSW, CANB, DNA); 10.3 m [miles] S Danger Point, Cobourg Peninsula, Chippendale NT 8228, 20 July 1961 (DNA, NSW); top of escarpment on track to top of Jim Jim Falls, Hill 4027 \& Stanberg, 4 Sep 1991 (NSW, BRI, CANB, DNA, MEL); Bluff W of Victoria River crossing, Hill 3349 Johnson \& Stanberg, 17 Nov 1988 (NSW).

Queensland: 29 km W of Einasleigh, Hind 2804, 20 Sep 1980 (NSW); 10 miles [16 km] W of Croydon, Johnson s.n., 20 Oct 1964 (NSW); Hells gate near Westmoreland, Carolin 9178, (NSW); 20.4 miles 
[32.8 km] from Walsh River Crossing towards Wrotham Park, Brooker 3373, 27 Jan 1972 (CANB, NSW); c. 2 km from Lappa on the road to Sunnymount, Clarkson 9172, 28 Dec 1991 (BRI, CANB, NSW); Stannary Hills Road 8 miles South of Mutchilba, Stocker 728, 31 May 1971 (QRS, NSW); 2.5 $\mathrm{km} \mathrm{S}$ of the Maitland Downs turn-off on the Peninsula Development Rd, Clarkson 6125, 30 July 1985 (BRI, MBA, NSW, PERTH, QRS); 9 km W of Gilbert River on Croydon Road, Benson 843, 19 June 1974 (NSW); $36 \mathrm{~km}$ from the Walsh River Crossing on the Mungana - Wrotham Park road, Clarkson 2810, 7 Feb 1980 (BRI, FRI, MO, NSW); $15 \mathrm{~km} \mathrm{SW} \mathrm{of} \mathrm{Pentland} \mathrm{towards} \mathrm{Lauderdale}$ homestead, Martensz 1245, 9 Oct 1978 (BRI, NSW).

Western Australia: 7 km S of Cape Leveque, Carter 298, 5 June 1988 (PERTH, NSW); on summit of hills, about the base of Mt Herbert, King Leopold Ranges, Symon 5327, 25 June 1967 (AD, NSW); Koolan Island, Wannan UNSW 20409, Jan 1974 (UNSW, NSW); 2 km N of King Edward R, Puttock UNSW 20678, 13 July 1987 (UNSW, BRI, CANB, NSW); Greville Island, Cunningham s.n., 1920 (NSW); Radio Hill, Wyndham, Johnson 2049, 24 Aug 1967 (NSW); Beverley Springs, Beard 4165, 18 May 1965 (PERTH, NSW); King Edward River, old CRA campsite, $1 \mathrm{~km} \mathrm{~S}$ of ford crossing by track to abandoned Mitchell River homestead, Edinger 240, 5 June 1987 (PERTH, NSW); 12 miles [19.2 km] SE of Kimberley Research Station, Perry 2931, 7 July 1952 (CANB, NSW).

\section{E. miniata $\times$ E. phoenicea}

Northern Territory: South Alligator River, 27 miles [43.2 km] SW of Jim Jim Crossing, Adams 2844, 15 July 1972 (CANB, BRI, CANB, DNA, K, L, NSW, US).

20. Eucalyptus gigantangion L.A.S. Johnson \& K.D. Hill, Telopea 4(2): 322 (1991).

Type: Northern Territory: Twin Falls, Kakadu National Park (13¹8'S 13251'E), C. Dunlop 6722 \& G. Wightman, 16 July 1984 (holo NSW, iso DNA).

Tree to $30 \mathrm{~m}$. Bark persistent on trunk, fibrous with soft, flexible fibres and included mica-like flakes, orange-brown to red-brown, weathering dark brown to black; smooth, white above. Juvenile leaves to $12 \mathrm{~cm}$ long and $5 \mathrm{~cm}$ wide, dull, green to bluish green, disjunct, petiolate, ovate to elliptical, with 'stellate hairs'. Adult leaves 6-14 cm long, 1-2 cm wide, dull, green to bluish green, disjunct, narrow- to broadlanceolate, acute, glabrous; petioles $12-20 \mathrm{~mm}$ long; lateral veins at c. $30^{\circ}$ to midrib,

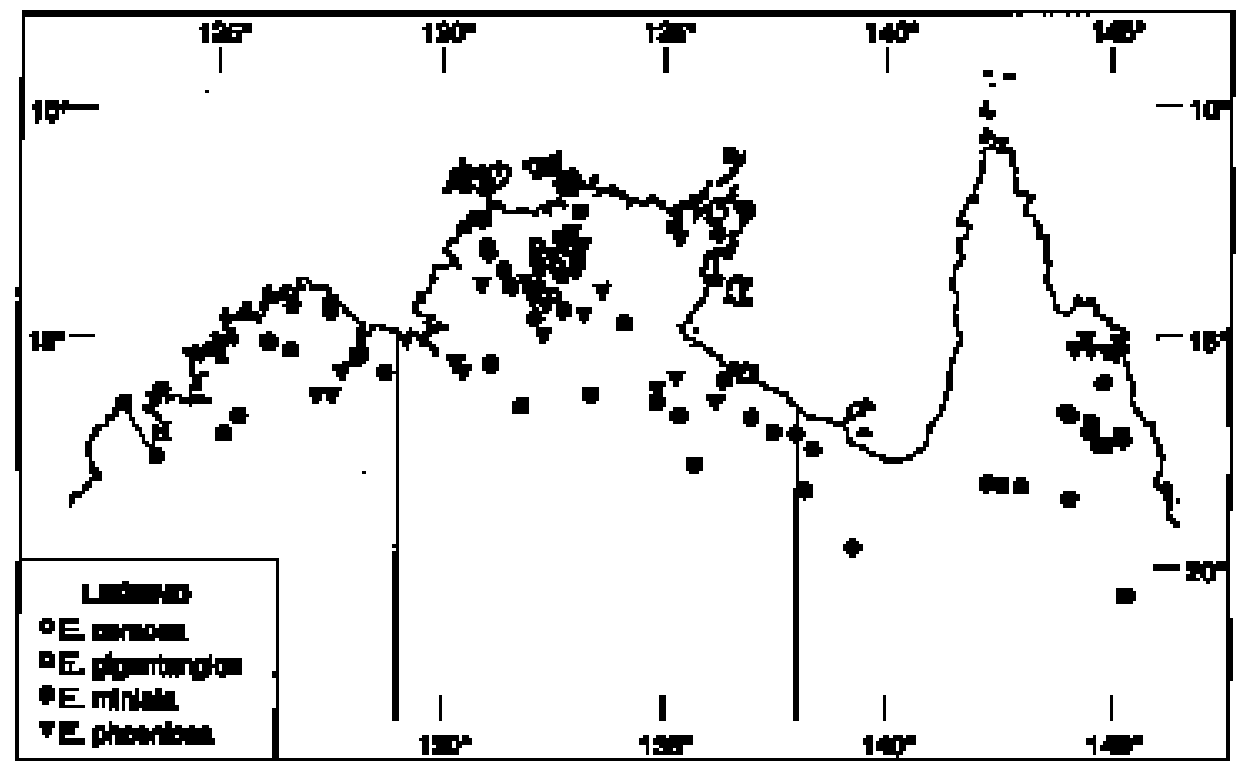

Fig. 14. Distribution of E. miniata, E. gigantangion, E. phoenicea and E. ceracea. 
moderately closely spaced; secondary reticulum incomplete; intramarginal vein irregular, c. $1 \mathrm{~mm}$ or less from leaf margin. Umbellasters simple, axillary, 7-flowered; peduncles terete or angular, 10-35 mm long; pedicels absent or terete, 0-5 mm long. Mature buds fusiform, \pm strongly ribbed, 18-25 mm long, 10-12 mm diam.; calyx indistinct, \pm fused to corolla, evident as 4 small teeth at apex of calyptra; calyptra hemispherical to conical, $1 / 2-2 / 3$ as long as hypanthium. Stamens all fertile, in a continuous ring; filaments regularly inflexed; anthers oblong, versatile, dehiscing through parallel slits. Fruits 3-locular, ovoid to urceolate,weakly ribbed, $45-70 \mathrm{~mm}$ long, 25-50 mm diam.; calyptra scar distinct and raised, disc 2-3 mm wide, level to slightly raised; valves enclosed. Seeds elliptical, dull, greyish black, not winged; hilum ventral; chaff angular, dark brown.

Distribution: locally abundant in Kakadu and north-western Arnhem Land in the N.T. (Fig. 14).

Ecology: a highly localised species dominating savanna forests on residual to skeletal sand over sandstone, with an understorey often dominated by Triodia and scleromorphic shrubs.

Conservation status: not considered to be at risk.

Selected specimens (from 7 examined): Northern Territory: Kakadu National Park, top of escarpment on track to top of Jim Jim Falls, Hill 4026 \& Stanberg, 4 Sep 1991 (NSW, BRI, CANB, DNA); Deaf Adder George. Southern Plateau, Kakadu National Park, Boland 2143 \& Wardman, 18 Nov 1984 (CANB, NSW); 41 miles [65.6 km] from Pine Creek to UDP Falls, Gittins 2716, Aug 1973 (NSW); Top of Twin Falls, Johnstone 150, 18 July 1989 (CANB, BRI, DNA); Twin Falls, Kakadu National Park, Dunlop 6722 \& Wightman, 16 July 1984 (DNA, NSW).

\section{Subseries Phoeniceosae}

Umbellasters more than 7-flowered.

21. Eucalyptus phoenicea F. Muell., J. Linn. Soc., Bot. 3: 91 (1850).

Type: Northern Territory: Victoria River, near the main camp, F. Mueller s.n. (lecto BRI, K, MEL; here designated). Figured by Mueller (Eucalyptographia) and Maiden (C.R. 3 , plate 96, Fig. 8). This is selected from a number of scattered syntypes (see Blake, 1953 and Chippendale, 1974), as it has been widely distributed and illustrated. The type citation was: 'Hab. In planitiebus elevatioribus collibusque saxosis vel arenosis a fluvio Victoria per terram Arnheim circum sinum Carpentaria. Anth. Jun. - Sept.'

Tree to $10 \mathrm{~m}$, sometimes to $20 \mathrm{~m}$. Bark persistent on trunk and larger branches, fibrous with soft, flexible fibres and included mica-like flakes, orange-brown to red-brown, weathering dark brown; smooth, greyish above. Juvenile leaves to $12 \mathrm{~cm}$ long and $6 \mathrm{~cm}$ wide, dull, green to bluish green, disjunct, petiolate, ovate to elliptical, with 'stellate hairs'. Adult leaves 7-12 cm long, 1.2-2 cm wide, dull, green to bluish green, disjunct, narrow- to broad-lanceolate, acute, glabrous; petioles 8-15 mm long; lateral veins at c. $30^{\circ}$ to midrib, moderately closely spaced; secondary reticulum incomplete; intramarginal vein irregular, c. $1 \mathrm{~mm}$ or less from leaf margin. Umbellasters simple, axillary, more than 11-flowered; peduncles terete or angular, 15-30 mm long; pedicels terete, 4-15 mm long. Mature buds ovoid to clavate, \pm ribbed, 7-10 mm long, $4-5 \mathrm{~mm}$ diam.; calyx indistinct, \pm fused to corolla, evident as 4 small teeth at apex of calyptra; calyptra hemispherical to conical, $1 / 2-2 / 3$ as long as hypanthium. Stamens all fertile, in a continuous ring; filaments regularly inflexed; anthers oblong, versatile, dehiscing through parallel slits. Fruits 3-locular, ovoid to cylindrical, distinctly urceolate, usually weakly ribed, 20-30 mm long, 9-13 mm diam.; calyptra scar distinct and raised, disc 2-3 mm wide, level to slightly raised; valves enclosed. Seeds elliptical, dull, greyish black, not winged; hilum ventral; chaff angular, dark brown. 
Distribution: northern Australia, widespread and abundant in W.A., N.T. and Queensland north of 15\%30' (Fig. 14).

Ecology: a locally abundant species although somewhat sporadic in distribution, dominating low open savanna woodlands on residual to skeletal sandy soils over sandstones, with an understorey often dominated by Triodia.

Conservation status: not considered to be at risk.

Selected specimens (from 61 examined): Northern Territory: $1.7 \mathrm{~km}$ W Koongarra Saddle, Tindale 10027 \& Munns, 27 July 1989 (NSW, CANB, NT, PERTH, BRI, MEL); 28 miles [44.8 km] SW of Katherine, Speck 1657, 21 Sep 1961 (CANB, NSW); between Ferguson \& Edith River, Brooker 3137, 17 June 1971 (CANB, NSW); 49 miles [78.4 km] by road NE of Maranboy Police Station, Brooker 4168, 18 Oct 1973 (CANB, NSW); 52.2 km E of Ramangining turn-off on Gove road, Hill $3923 \mathcal{E}$ Stanberg, 25 Aug 1991 (NSW, CANB, DNA); near the turn-off to Edith Falls, N of Katherine, Symon 5139, 9 June 1967 (AD, CANB, NSW, NT); $11 \mathrm{~m}$ [miles][17.6 km] S of Pine Creek, Jacobs 102, 25 July 1933 (NSW); Crest of hill on turn-off $5.4 \mathrm{~km} \mathrm{~W}$ of Timber Creek roadhouse, c $5 \mathrm{~km}$ along track to E, Hill 3355 Johnson \& Stanberg, 18 Nov 1988 (NSW); 9 miles W of Timber Creek, Gittins 1361, July 1967 (NSW).

Queensland: ca. $2.6 \mathrm{~km}$ from the beach S of South Cape Bedford on the track to Elim. Vegetation site BED 6, Clarkson 8700 \& Neldner, 23 May 1990 (BRI, K, MBA, MEL, NSW, QRS); 25 km from Old Laura towards Battle Camp, Hill 1918 Hind \& Healey, 2 Aug 1986 (NSW, BRI, FRI, PERTH); 14 km NW of New Laura Ranger Station, Neldner 4000, 25 May 1992 (BRI, MBA, NSW).

Western Australia: ca 4 km E of Bindoola Ck., on Gibb River-Wyndham road, George 15223, 27 June 1978 (PERTH, NSW); 55 miles [88 km] SW of Wyndham Township, Perry 3081, 28 July 1952 (CANB, NSW); 182 km W Kununurra, Gibb rd, Kimberleys, Guymer 558, 31 Aug 1976 (BRI, NSW); 27 miles [43.2 km] NE of Karunjie station, Speck 5016, 15 Sep 1954 (CANB, NSW); 50 m (80 km) SW of Wyndham pumping station, Maconochie 142, 19 May 1967 (DNA, NSW).

22. Eucalyptus ceracea Brooker \& Done, Nuytsia 5(3): 382 (1986).

Type: Western Australia: $33 \mathrm{~km}$ SE of King George Falls, Kimberley district $\left(14^{\circ} 18^{\prime} \mathrm{S}\right.$, $127^{\circ} 29^{\prime} \mathrm{E}$ ), 14 July 1982, C. Done 612 (holo PERTH; iso CANB, NSW).

Tree to $4 \mathrm{~m}$, usually with several trunks. Bark persistent throughout, fibrous with soft, flexible fibres and included mica-like flakes, orange-brown to red-brown. Juvenile leaves to $12 \mathrm{~cm}$ long and $6 \mathrm{~cm}$ wide, dull, green to bluish green, opposite, sessile, ovate to elliptical, with 'stellate hairs'. Adult leaves 7-10 cm long, 3-5.5 cm wide, dull, green to bluish green, opposite, sessile, ovate, obtuse, glabrous; lateral veins at c. $30^{\circ}$ to midrib, moderately closely spaced; secondary reticulum incomplete; intramarginal vein irregular, c. $1 \mathrm{~mm}$ or less from leaf margin. Umbellasters simple, axillary, 7-9flowered; peduncles terete or angular, 20-40 mm long; pedicels terete, 2-7 mm long. Mature buds clavate to pyriform, ribbed, 11-15 $\mathrm{mm}$ long, 7-9 mm diam.; calyx indistinct, \pm fused to corolla, evident as 4 small teeth at apex of calyptra; calyptra hemispherical to conical, $1 / 2-2 / 3$ as long as hypanthium. Stamens all fertile, in a continuous ring; filaments regularly inflexed; anthers oblong, versatile, dehiscing through parallel slits. Fruits 3-locular, cylindrical to ovoid, distinctly urceolate, $20-25 \mathrm{~mm}$ long, 10-15 mm diam.; calyptra scar distinct and raised, disc 2-3 mm wide, level to slightly raised; valves enclosed. Seeds elliptical, dull, greyish black, not winged; hilum ventral; chaff angular, dark brown.

Distribution: northern W.A., northern Kimberley region (Fig. 14).

Ecology: a rare and restricted species occurring in mixed open savanna woodlands with a range of associated species including Corymbia arenaria on skeletal sandy soils over sandstones, with an understorey dominated by Triodia.

Conservation status: not immediately threatened, but restricted in distribution. Conservation status 2R- (Briggs \& Leigh 1988). 
Selected specimens (from 6 examined): Western Australia: $103.2 \mathrm{~km} \mathrm{~W}$ of King George River Crossing, Hill 954, Johnson \& Benson, 25 July 1984 (NSW); Kimberley Casurin Ck, King George 1 12 km E of King George River, Brooker 7771, 1 Nov 1982 (CANB, NSW); Seppelt Range, 13 km by track from King George River Crossing, Done 796, 10 July 1989 (NSW).

\section{Acknowledgments}

Our colleague in the overall project, Don Blaxell, has contributed helpful discussions and has been involved in the recognition of several of the taxa. Barbara Briggs is gratefully acknowledged for valuable encouragement, support and assistance. Thanks are also due to David Mackay, who prepared the illustrations, Leonie Stanberg, who has provided extremely valuable technical and editorial assistance through the project, and Peter Wilson for valuable critical comment on the mansucript.

\section{References}

Bentham, G. (1867) Flora Australiensis, vol. 3.

Blake, S.T. (1953) Botanical contributions of the Northern Australia Regional Survey. Studies of northern Australian species of Eucalyptus. Austral. J. Bot. 1: 185-352.

Blakely, W.F. (1934) A Key to the Eucalypts. (The Worker Trustees: Sydney).

Briggs, J. \& Leigh, J. (1996) Rare or Threatened Australian Plants. Australian National Parks \& Wildlife Service, Special Publication no. 14.

Brooker, M.I.H. \& Kleinig, D.A. (1990) Field Guide to Eucalypts, vol 2. (Inkata: Melbourne).

Brown, R. (1814) Appendix, in M. Flinders, Voyage Terra Australis, vol. 2.

Carr, S.G.M. \& Carr D.J., (1963) The taxonomic position of certain eucalypts. Proc. Roy. Soc. Victoria 77: 207-216.

Carr, S.G.M. \& Carr D.J., (1968) Operculum development and the taxonomy of eucalypts. Nature 219: 523-525.

Chippendale, G.M. (1974) Herbarium specimens of Eucalyptus photographed in Europe. Technical note 7. (Forestry and Timber Burea: Canberra).

Chippendale, G.M. (1988) Eucalyptus, Angophora. In A.S. George (ed.), Flora of Australia, vol. 19. (Australian Government Publishing Service: Canberra).

Drinnan, A.N. \& Ladiges, P.Y. (1989) Operculum development in the Eudesmieae B eucalypts and Eucalyptus caesia (Myrtaceae). Plant Syst. Evol. 165: 227-237.

Drinnan, A.N. \& Ladiges, P.Y. (1989) Corolla and androecium development in some Eudesmia eucalypts (Myrtaceae). Plant Syst. Evol. 165: 239-254.

Drinnan, A.N. \& Ladiges, P.Y. (1991) Floral development and systematic position in Eucalyptus curtisii (Myrtaceae). Austral. Syst. Bot. 4: 539-551.

Farris, J.S. (1988) Hennig86. Published privately.

Hill, K.D. \& Johnson, L.A.S. (1995) Systematic studies in the eucalypts. 7. A revision of the bloodwoods, genus Corymbia (Myrtaceae). Telopea 6: 185-504.

Jessop, J.P. (1986) Flora of South Australia. Part II. Leguminosae-Rubiaceae. (Govt Printer: Adelaide).

Johnson, L.A.S. (1972) Evolution and classification in Eucalyptus. Proc. Linn. Soc. New South Wales 97: 11-29.

Johnson, L.A.S. \& Briggs, B.G. (1984) Myrtales and Myrtaceae - a phylogenetic analysis. Ann. Missouri Bot. Gard. 71: 700-756.

Ladiges, P.Y. (1984) A comparative study of trichomes in Angophora Cav. and Eucalyptus L'Herit. Austral. J. Bot. 32: 561-574.

Ladiges, P.Y. \& Humphries, C.J. (1983) A cladistic study of Arillastrum, Angophora and Eucalyptus (Myrtaceae). J. Linn. Soc., Bot. 87: 105-134.

Ladiges, P.Y., Udovicic, F. \& Drinnan, A.N. (1995) Eucalypt phylogeny - molecules and morphology. Austral. Syst. Bot. 8: 483-497.

Maiden, J.H. (1903-33) A Critical Revision of the Genus Eucalyptus. (Govt. Printer: Sydney). 
Mueller, F. (1878) Fragmenta phytographiae Australiae 11: 11-12.

Mueller, F. (1882) Systematic census of Australian plants.

Mueller, F. (1879-84) Eucalyptographia.

Pryor, L.D. \& Johnson, L.A.S. (1971) A Classification of the Eucalypts. (ANU Press: Canberra).

Manuscript received 25 September 1997

Manuscript accepted 16 April 1998 